\title{
Developing Lifelong Online Learning for Students through Constructivism and Massive Open Online Courses (MOOCs)
}

Mahmood Ekrami ${ }^{1}$ Associate Professor, Payame Noor University, Tehran, Iran (Corresponding Author).

Mohammad Reza Sarmadi ${ }^{2}$ Professor, Payame Noor University, Tehran, Iran.

Leila Vatan Doust ${ }^{3}$ M.A.Student of Educational Management, Payame Noor University, Tehran, Iran.

\begin{abstract}
The purpose of this study was to enhance lifelong learning based on constructivism and massive open online courses (MOOCs). Constructivism is defined basically as a learning approach, in which students subjectively construct, interpret and reorganize their knowledge. MOOCs are online courses that facilitate open access to learning at a large scale. Lifelong learning is defined as self-directed and self-regulated learning. The statistical population was composed of Ph.D and M.A students having at least one-year experience in E-learning environments. Based on self-expression, a sample of 161 individuals was selected using random sampling method. Data gathering tool was a questionnaire consisting of 67 items in the above three themes: constructivism, MOOCs, and lifelong learning. The total variance of questionnaires and their construct validity was confirmed applying exploratory factor analysis. Path analysis model was implemented and the results are as follows: constructivism has positive and significant effect on lifelong learning through MOOCs, but it has no direct or significant effect on lifelong learning. Also, in the final model, such factors as uncertainty, time management, and adaptable learning strategies were removed from constructivism, MOOCs and lifelong learning, respectively.
\end{abstract}

Keywords: Constructivism, Lifelong Learning, Massive Open Online Courses (MOOC), E-learning, Path Analysis.

1.m.ekrami@pnu.ac.ir

2. sarmadi@pnu.ac.ir 
عنوان مقاله: توسعه يادكيرى مستمر برخط دانشجويان بر

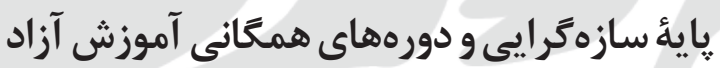

$$
\text { برخط (موك) }
$$

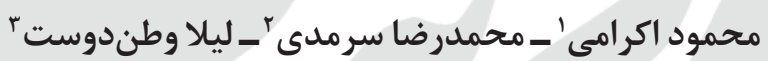

\section{جكيل:}

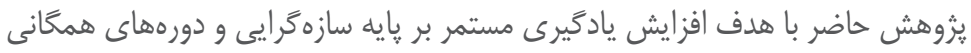

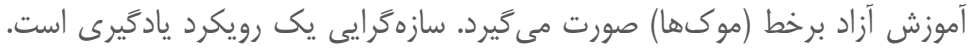

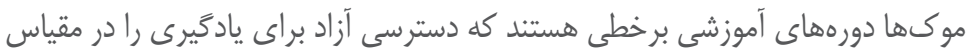

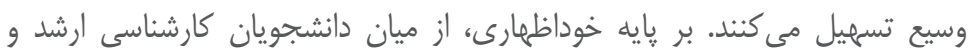

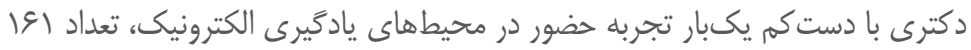

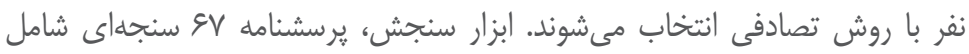

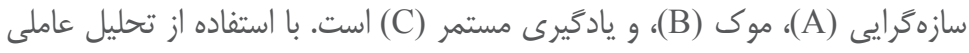

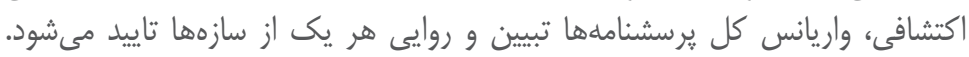

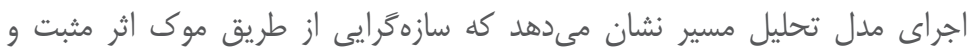

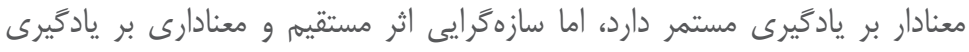

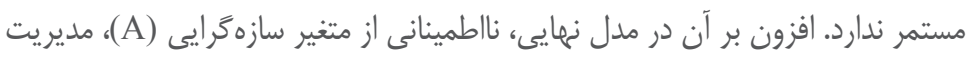

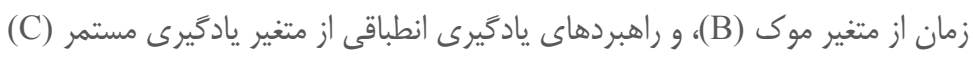

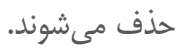

كليدوازهها: سازه گرايى، ياد گيرى مستمر، دورههاى همكانى آموزش

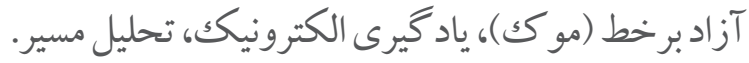




\section{مقام}

يادگيرى و بهطور كلى دانستن ميل ذاتى انسانهاست، اما گَاهى مشكلات مانع از تحقق

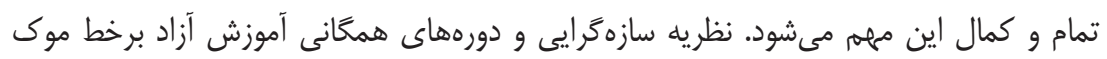
(MOOCs)

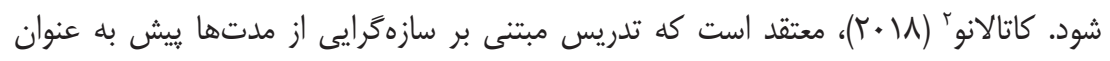

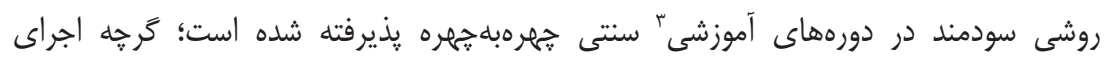
روشهاى تدريس مبتنى بر سازهرايى در دورههاى آموزشى برخط دشوارتر است. از طرفى،

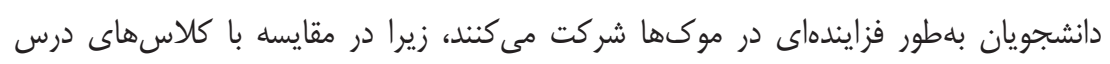

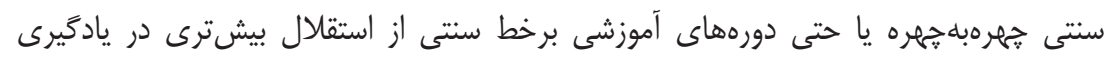

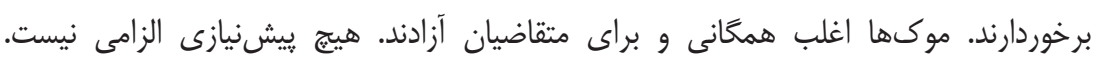
دانشآموزانى كه در حالت عادى قادر نيستند به آموزشهاى بعد از دبيرستان دسترسى يابند،

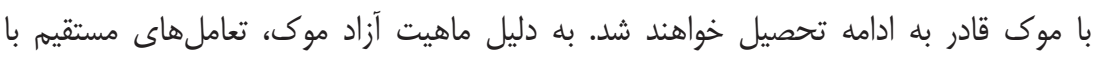

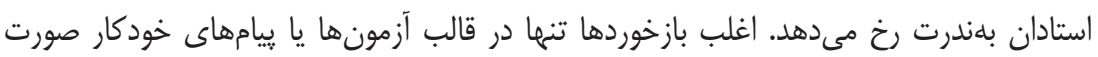
مىيذيرد. بنابراين، دانشجويان بايد در خصوص تكاليف و موفقيت در آنها برناملريزى كنند و بـاني

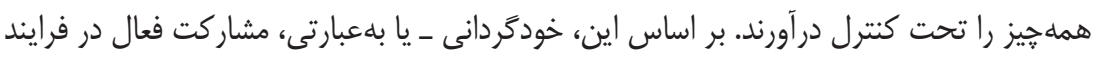

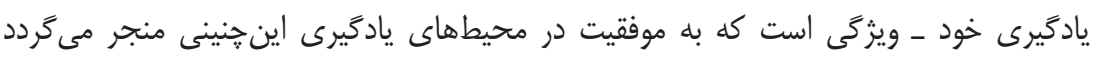

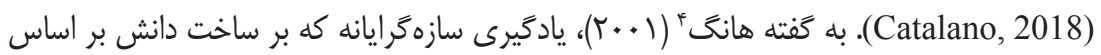
تجربههاى ييشين يادگيرنده متمركز است، براى محيطهاى يادگيرى الكترونيى نيز مناسب

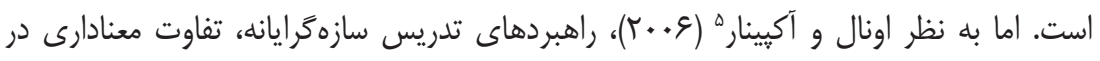
رويكردهاى يادگيرى دانشجويان ايجاد نمى كند، و نشان مى بـدهند كه نتايج معلول ناديده گرفتن

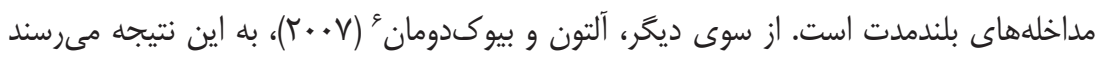

1. Massive Open Online Courses (MOOCs)

2. Catalano

3. Course

4. Hung

5. Unal \& Akpinar

6. Altun \& Büyükduman 


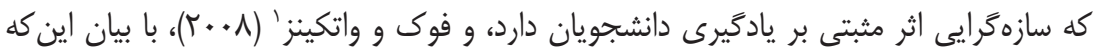

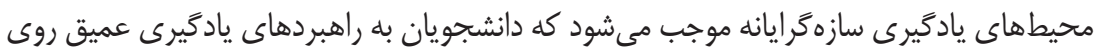

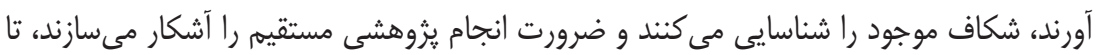

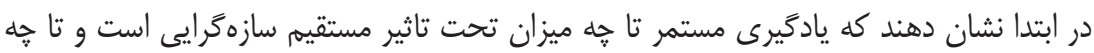
ميزان تحت تاثير عوامل ميانى مانند موكهاست.

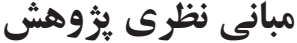

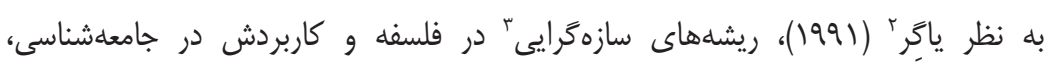
مردمشناسى، روانشناسى شناختى، و تعليموتربيت است. خاستخاه سازهگ ايى در انقلاب شناختى بـ

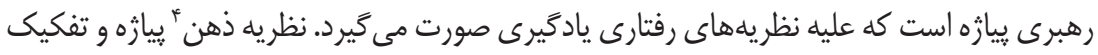
يديده شناختنايذير از بديده شناختيذير، مولفه مهمى براى سازهگرايان است (Zahorik, 1995).

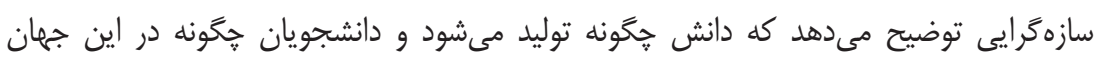

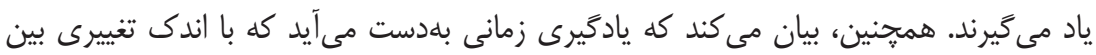
تجربه ييشين و تجربه جديد دانشجو، ارتباط برقرار شود (Chen \& Bennett, 2012). در نتيجه، مئه دانشجويان ركن اصلى و مدرسان فقط تسهيل كننده هستند (Chen \& Bennett, 2012). بـ

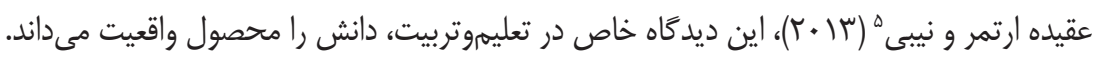
شناخترايان` ذهن را ابزار مرجعى براى جهان مىيندارند، اين در حالى است كه به عقيده

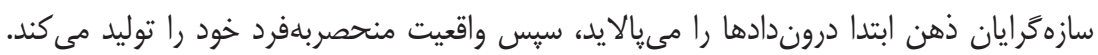

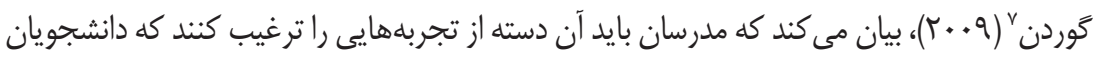

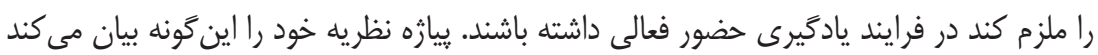
كه دانش فعالانه توسط افرادى كه با محيط در تعامل هستند، ساخته مى شود، بنابراين دانش نه

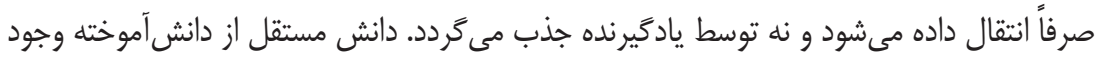
ندارد. فرد نظام دانش خود را با تكيه بر تجربياتش مىسازد (Kamii \& Ewing, 1996). تر كمن

1. Fok \& Watkins

2. Yager

4. Theory of Mind

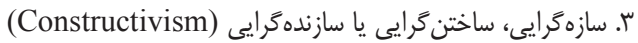

5. Ertmer \& Newby

6. Cognitivists

7. Gordon 


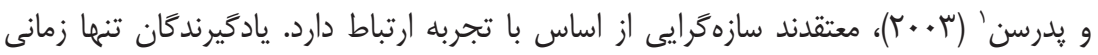

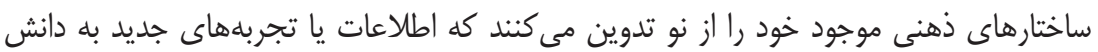

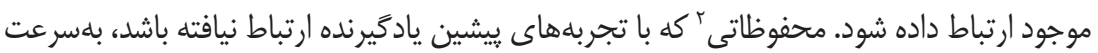
بهدست فراموشى سيرده مىشود. بلطور خلاصه، يادكيرنده بايد فعالانه اطلاعات جديد را درون

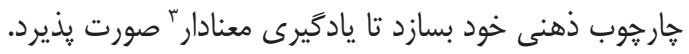

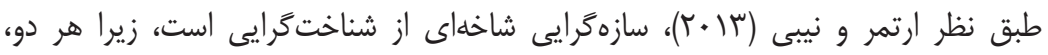

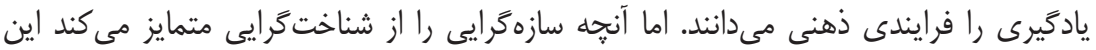

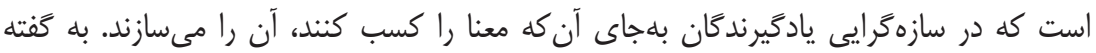

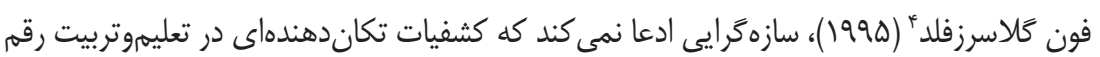
مىزند؛ تنها ادعاى سازمكرايى اين است كه زيرساخت مفهومى مستحكمى را براى برخى جيزها

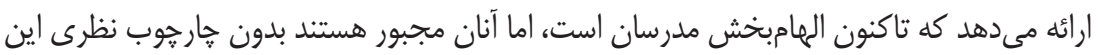

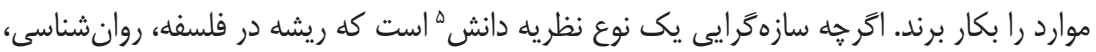

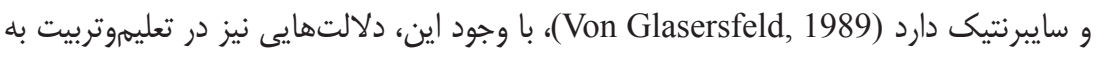
عنوان نظريه آموزشى غالب در هرخهاه آماى آموزشى معاصر داشته است (Krahenbuhl, 2016).

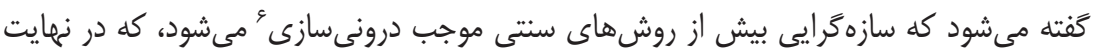

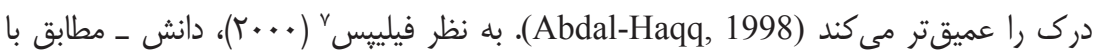

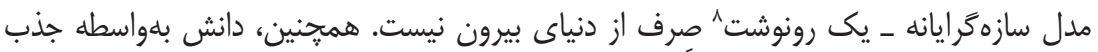

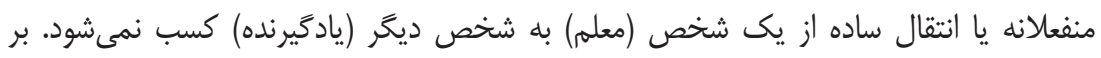

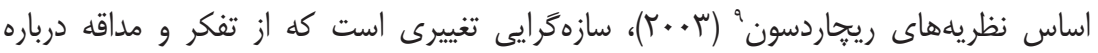

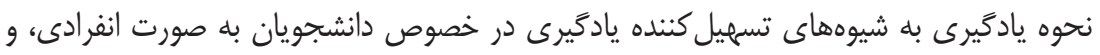

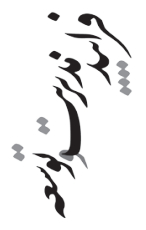

1. Turkmen \& Pedersen

3. Meaningful Learning r. منظور اطلاعات يا دادههاى به ياد سيرده شده است.

4. Von Glasersfeld

5.Theory of Knowledge

6. Internalization

7. Phillips

8. Copy

9. Richardson 
سيس در ميان كروههاى دانشجويى و كلاسهاى درس صورت مى يذيرد. سازمكرايى به عنوان

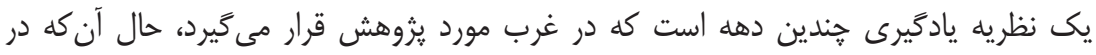

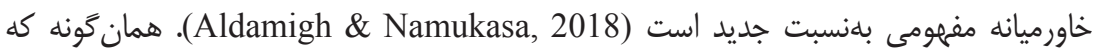

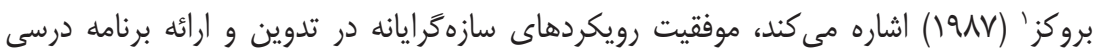

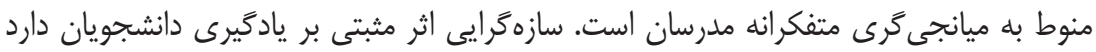

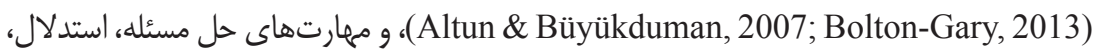
يرسش كرى، و شناسايى وجوه تشابه و تمايز را در آنان تقويت مى كندّ.

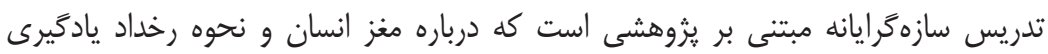

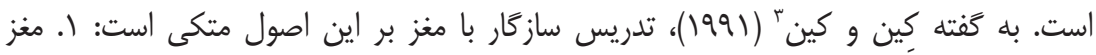

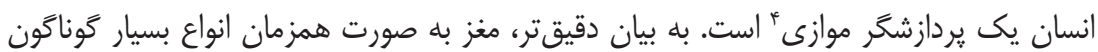

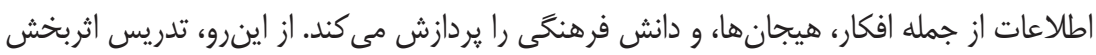

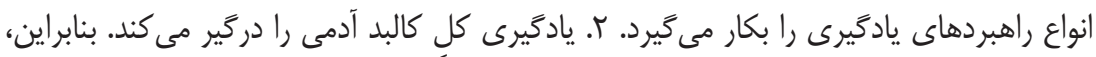

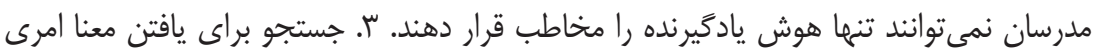

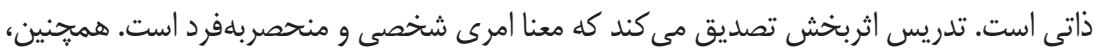

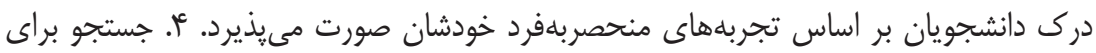

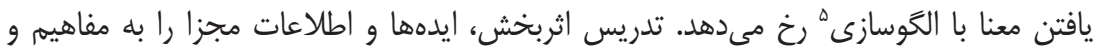

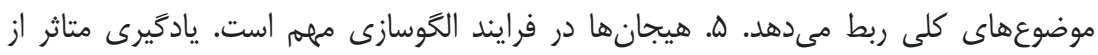

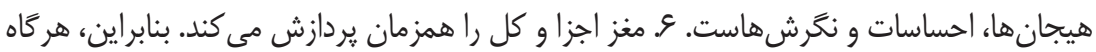

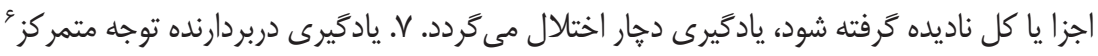

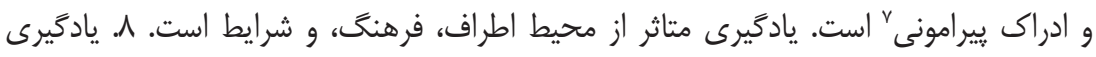

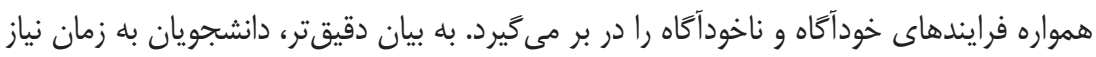

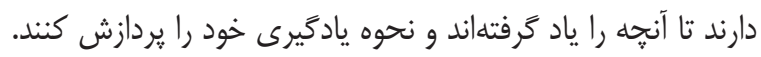

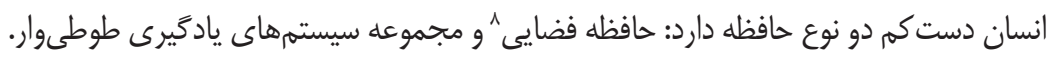

1. Brooks

2. https://www.thirteen.org/edonline/concept2class/constructivism/

3. Caine \& Caine

4. Parallel Processor

5. Patterning

6. Focused Attention

7. Peripheral Perception

8. Spatial Memory 


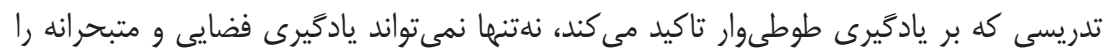

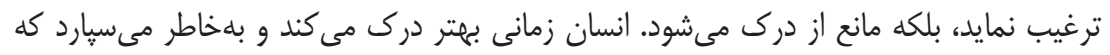

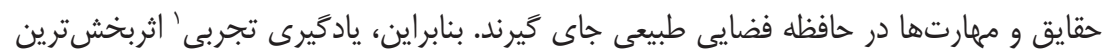

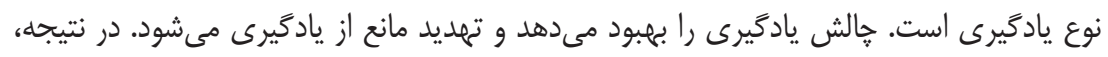

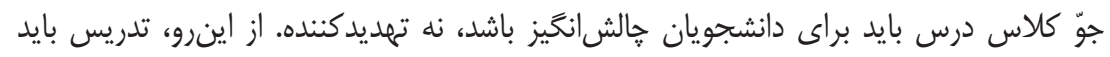
קندوجهى باشد تا دانشجويان بتوانند ترجيحهاى خود را باز كو كنند.

طبق نظر متخصصان، يادگيرى از دور در سه نسل يديدار مى شود كه عبارتاند از آموزشهاى

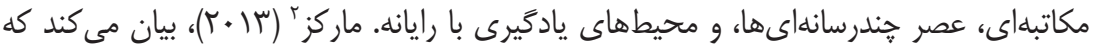

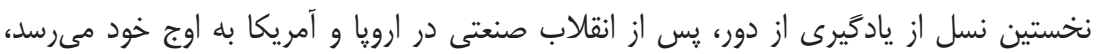

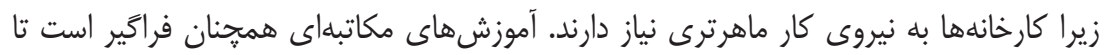

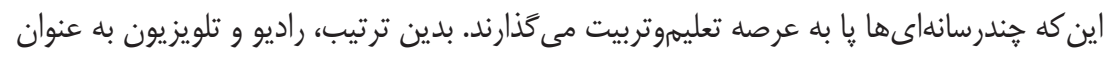

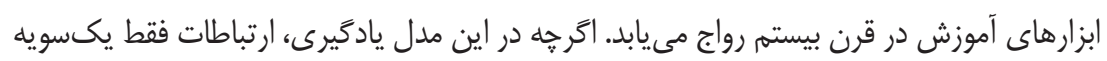

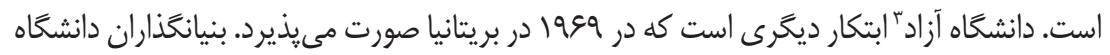

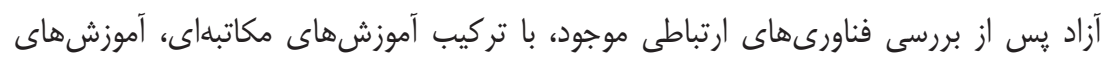

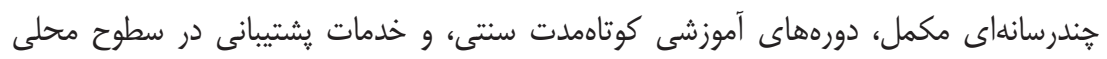

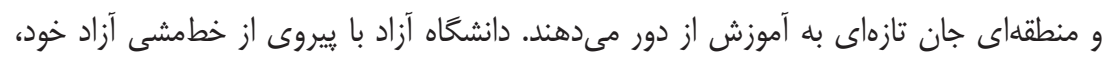

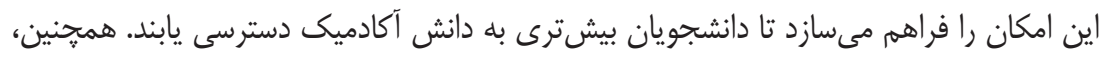

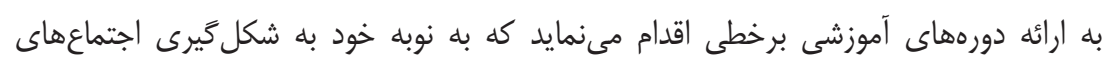
قدرتمندى از دانشجويان در بسيارى از كشورها منجر مى شودد. اين امر شباهت بسيارى به فلسفه

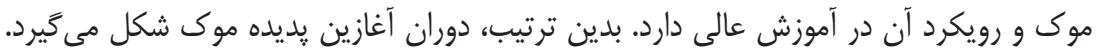

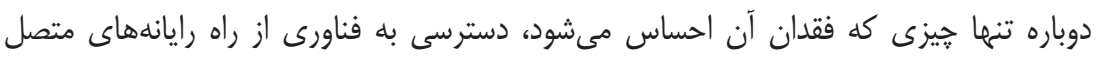

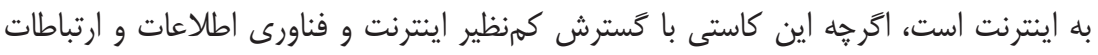

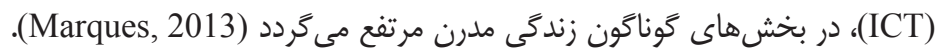

1. Experimental Learning

2. Marques

3. Open University 


\section{موكها و خار جوبهاى نظرى آن}

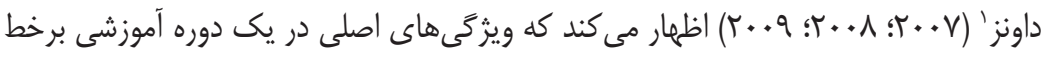

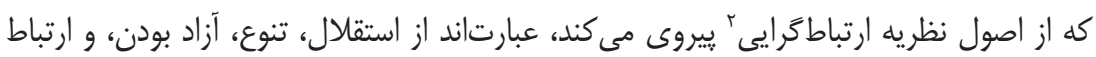

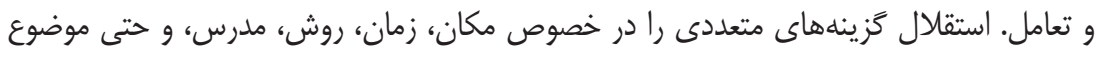

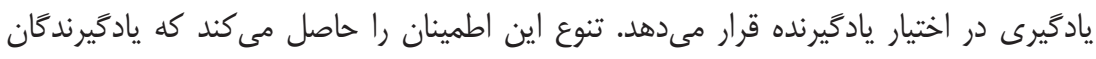

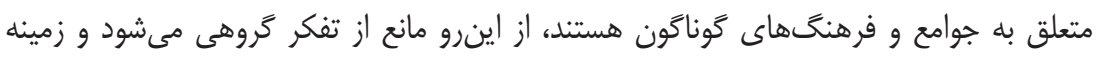

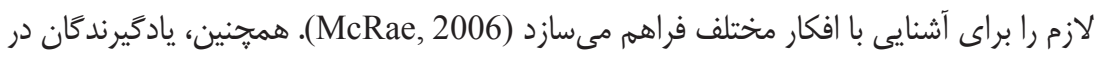

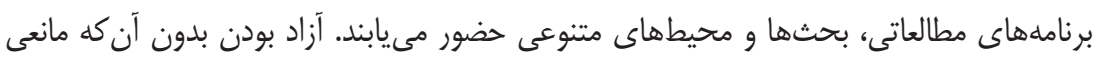

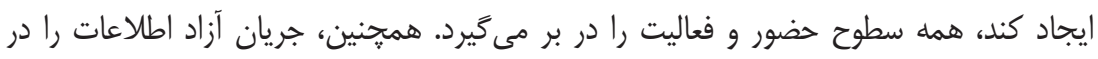

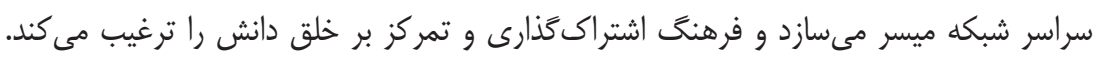

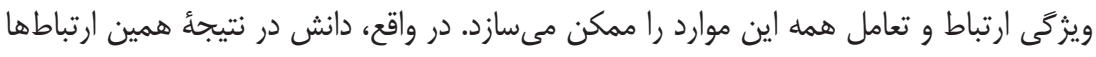
קيديدار مى شود.

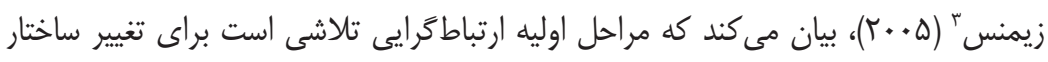

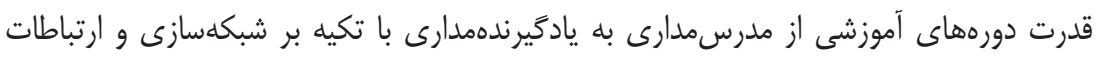

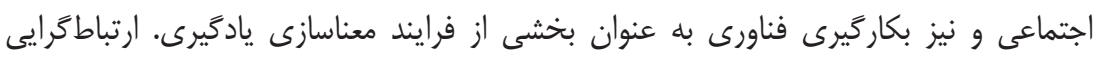

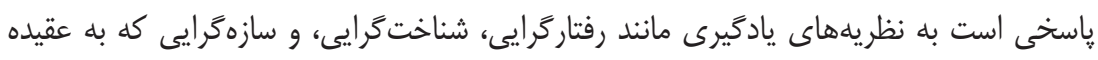

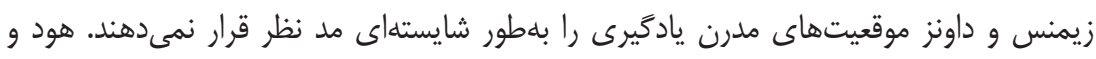

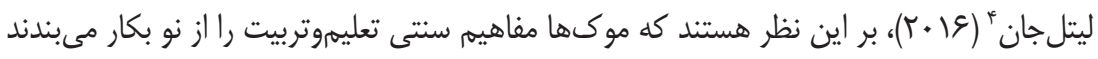

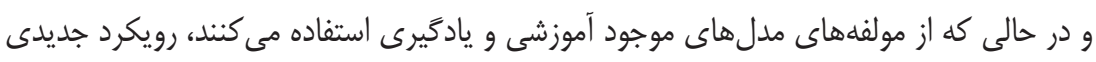

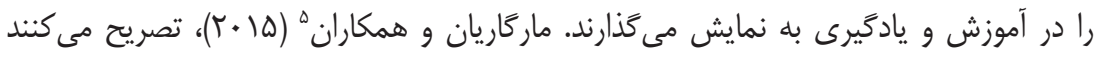

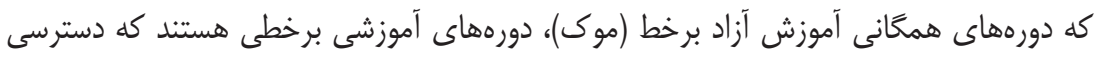

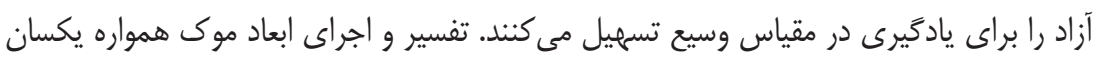

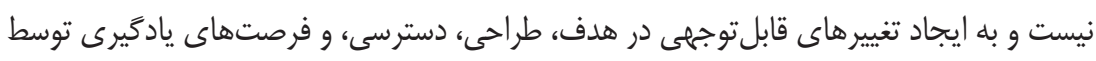

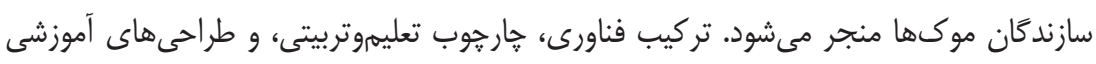

1. Downes

2. Connectionism

3. Siemens

4. Hood \& Littlejohn

5. Margaryan et al. 
در موكها تفاوتهاى قابلتوجهى با يكديگر دارد. برخى موكها مدلهاى آفلاين' تدريس و

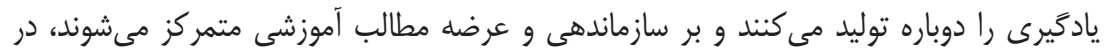

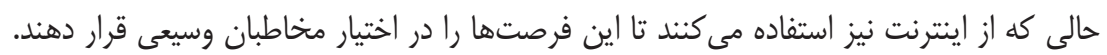

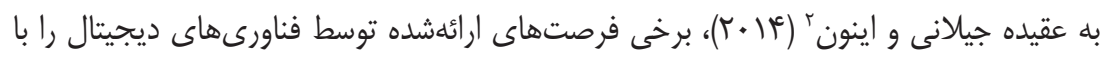

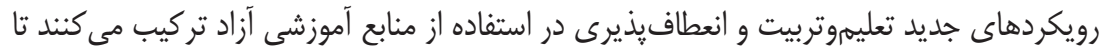
تجربdهاى جديدى از يادگيرى طراحى كنند.

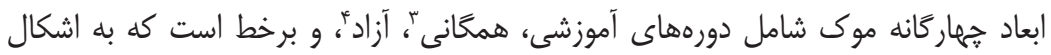

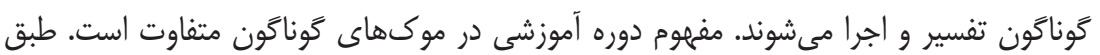

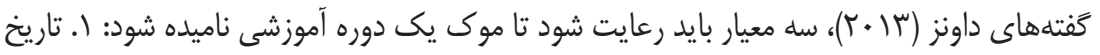
شروع و خاتمه مشخص؛ ז. موضوع يا بحث مشترك؛ و س. توالى از رويدادهاى منظه. موكها بلمور معمول دهار محدوديتهايى هستند كه به شيوههاى مختلفى آشكار مىشود. موكىها در

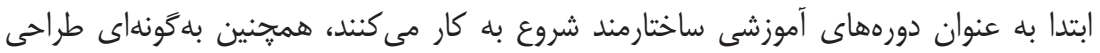

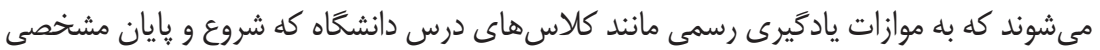

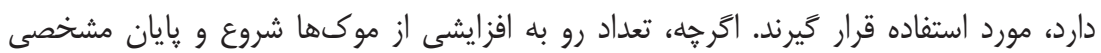

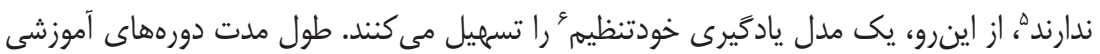

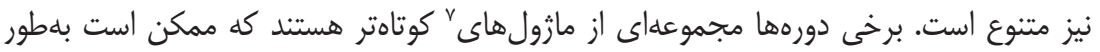
مستقل طى شود يا با همديخر تركيب شوند و تجربه يادَّيرى طولانىترى رقم زنند. الكوهاى

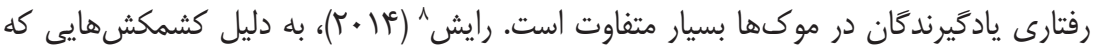

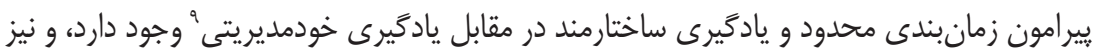

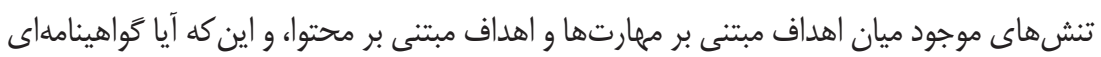
داده مىشود (يا بهراستى يادَيرندكان استحقاق دريافت آن را دارند)، اين مسئله را مطرح مى كنداند

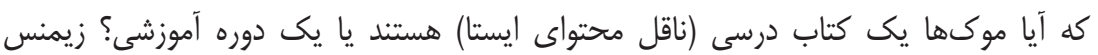

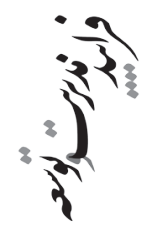

2. Gillani \& Eynon

ا. آفلاين (Offline) در مقابل برخط يا آناين (Online) قرار مى گيرد.

3. Massive

4. Open

5. https://www.edsurge.com/news/2015-12-28-moocs-in-2015-breaking-down-the-numbers

6. Self-Paced

7. Module

8. Reich

9. Self-Directed Learning 
(T/ (T)، بر اين نظر است كه تنش اصلى در مفهومسازى موكها، بين مدل انتقال و مدل ساخت

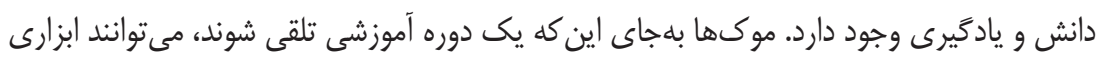

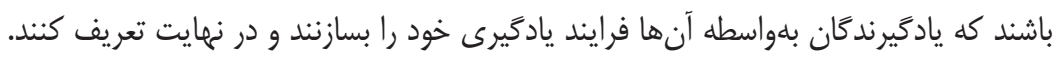

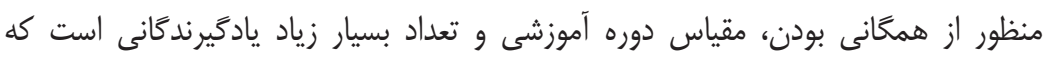

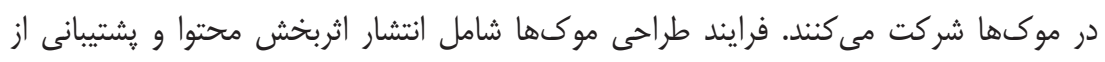

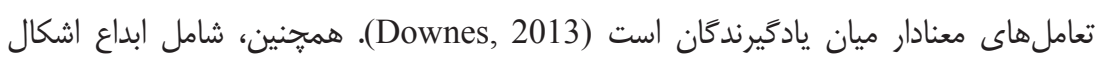

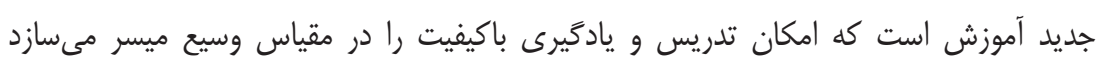

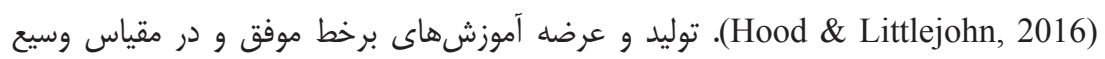

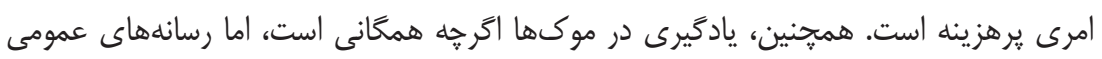

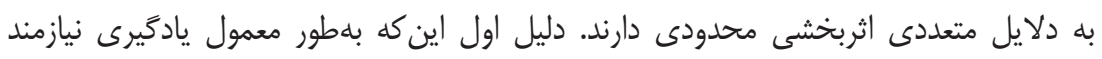

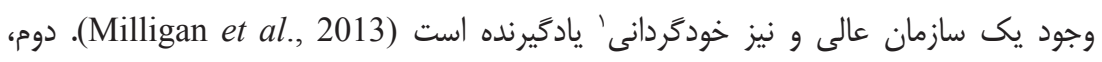

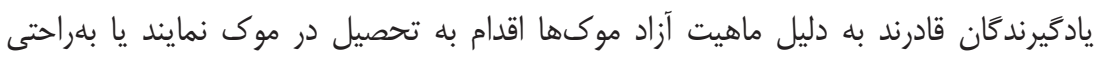

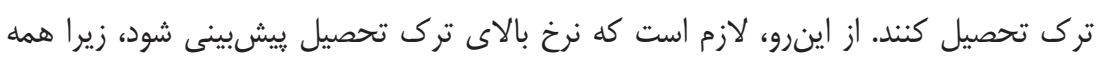

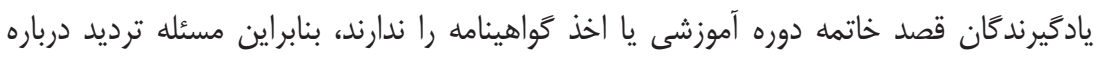

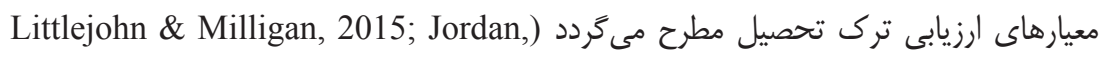

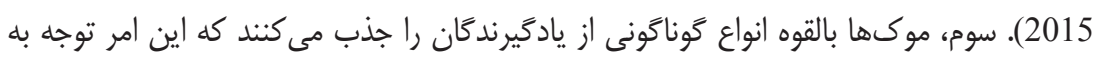

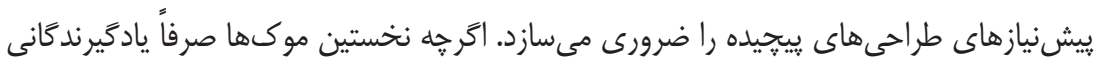
را جذب مى كرد كه ييشتر در دانشخاهها تحصيل كرده بودند (Zhenghao et al., 2015).

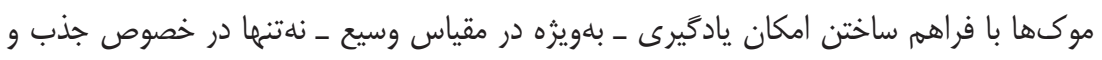

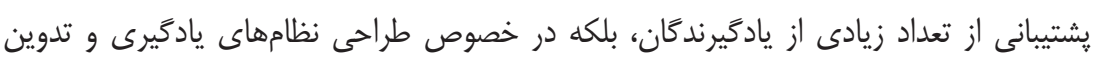

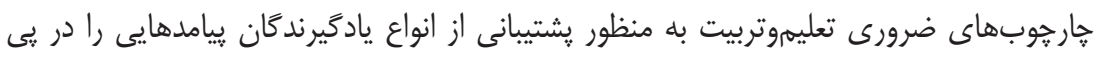

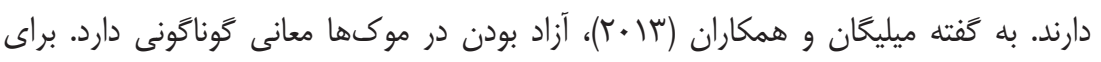

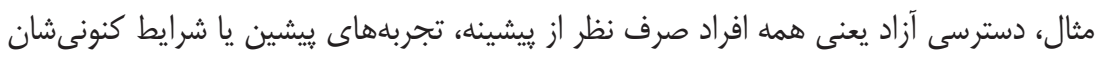

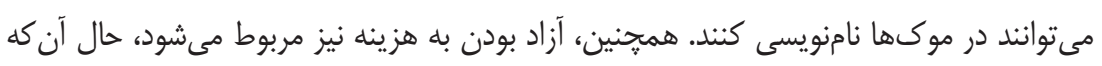

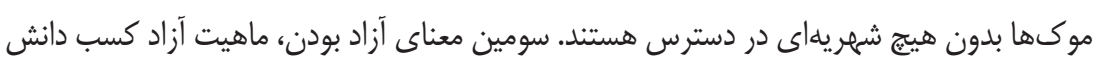

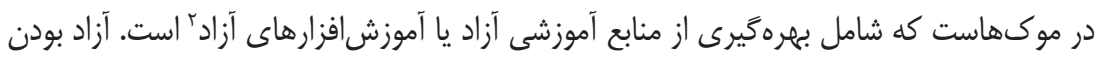

1. Self-Regulation

2. Open Course Ware (OCW) 
به توليد دانش و فرصت درآميختن و بكاركيرى مجدد منابع موجود توسط مدرسان و يادَّيرندكان،

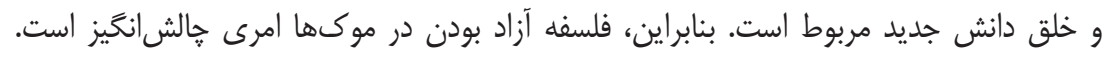

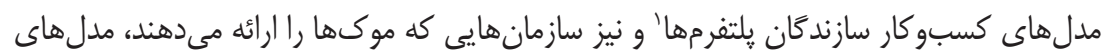

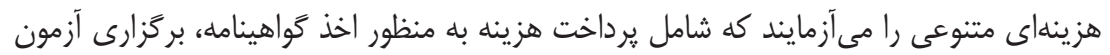

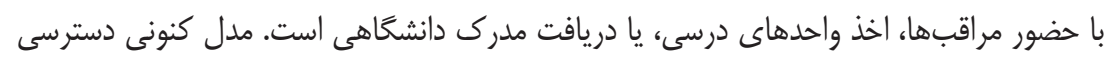

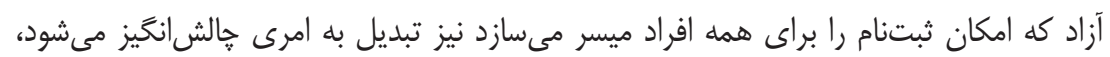

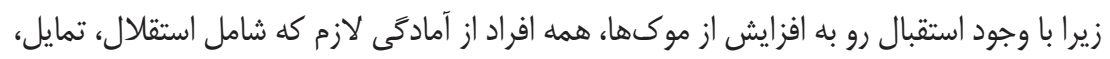

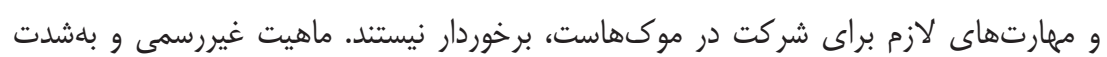

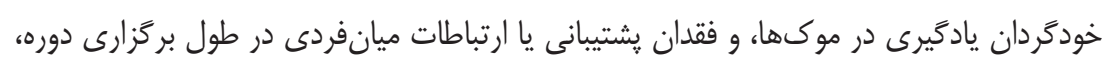

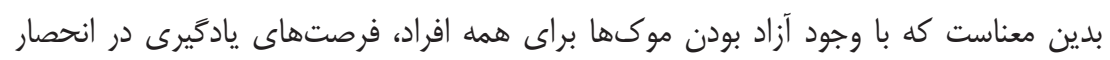

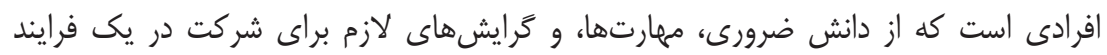
مستقل يادكيرى برخوردارند.

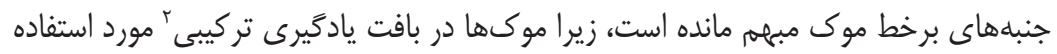

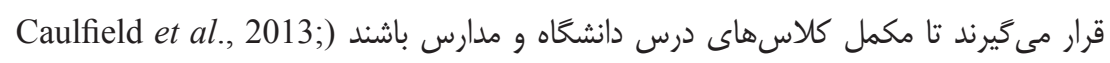
(Holotescu et al., 2014; Firmin et al., 2014; Bruff et al., 2013 با مرورى بر شواهد موجود يبرامون ادغام موكها در بافت يادگّيرى آفلاين به اين نتيجه مىرسد

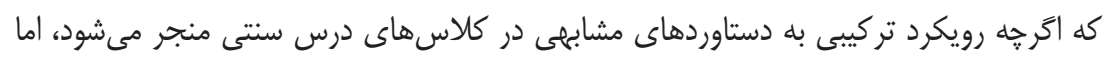

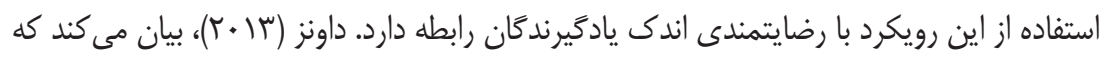

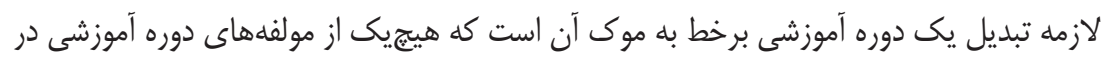

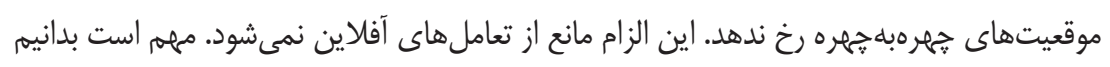

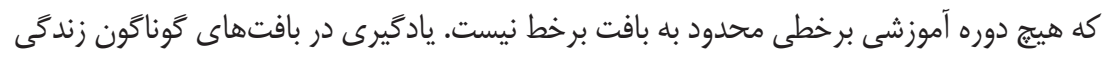

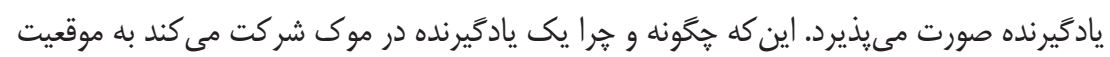

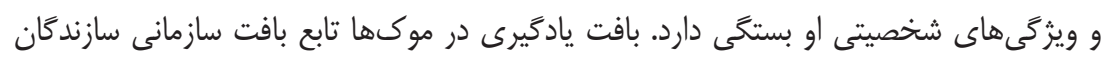

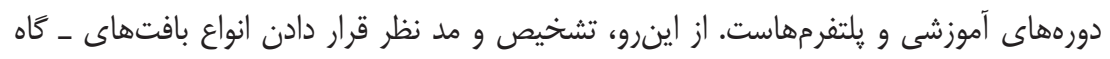

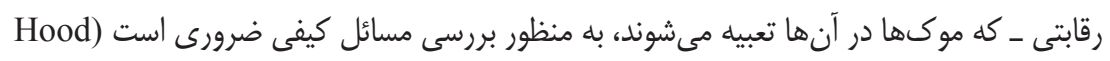

.\& Littlejohn, 2016

1. Platform

2. Blended Learning

3. Israel 


\section{يادَّيرى خودَّردان در موكها}

همانطور كه كفته شد، شمار دانشجويان شركتكننده در موكها بهسرعت در حال افزايش است. به دليل استقلال يادَّيرنده در اين نوع آموزش، دانشجويان موك در مقايسه با دانشجويان دورههاى سنتى بايد بيشتر بر فرايند يادكيرى خود نظارت داشته باشند. شايان اشاره است كه افزايش آموزش برخط حالشهاى خاص خود را دارد. موكها نهتنها از لحاظ دسترسى، بلكه از لحاظ

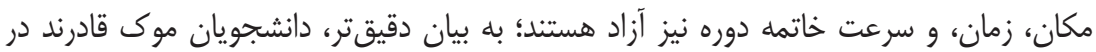

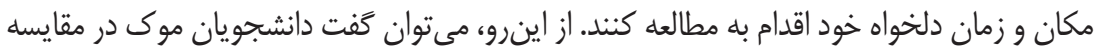

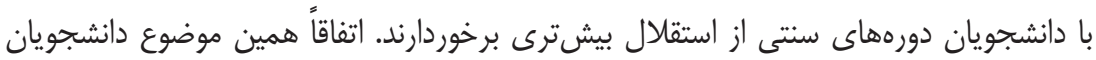

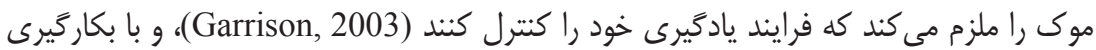
راهبردهاى متفاوت بر رفتارهاى مطالعاتى خود نظارت كنند (Dillon \& Greene, 2003)

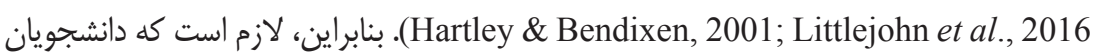
در خصوص فعاليتهاى خود فعالانه برنامهريزى كنند، اهداف خود را تعيين نمايند، زمان مورد نياز را براى يادكيرى تخمين بزنند، و درى خود را از آموزشها ارزيابى كنند. به مجموعه اين اقدامها

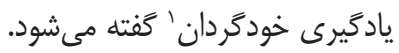

\section{رويكرد يادَّيرى عميق و رويكرد يادَيرى سطحى}

يادَيرى عميقَ و يادَيرى سطحى" دو رويكرد اصلى يادَيرى بهشمار مىروند. افراد بيرو

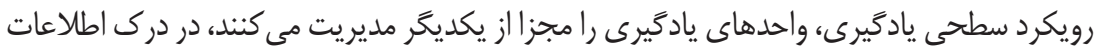

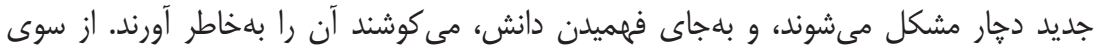
ديكر، براى افراد يبرو رويكرد عميق، يادَيرى شامل جستجو براى يافتن مدارك و شواهد، برقرار

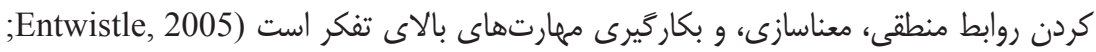

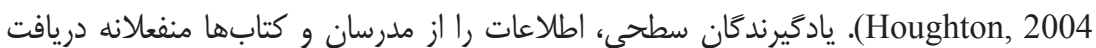
مى كنند، از اينرو دانش جديد را بهراحتى فراموش مىنمايند. اين در حالى است كه يادَّيرندكان

1. Self-Regulated Learning (SRL)

2. Deep Learning

3. Surface Learning 
عميق با ايجاد ارتباط بين دانش موجود و دانش جديد، معناى خود را مىسازند، و آموختههاى

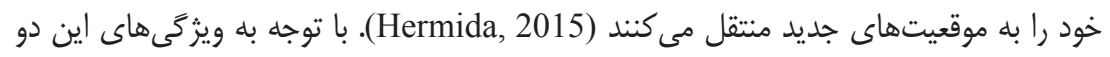

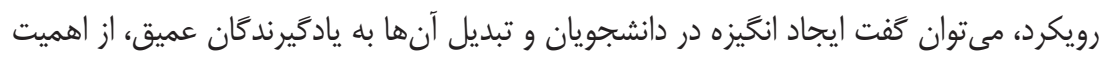

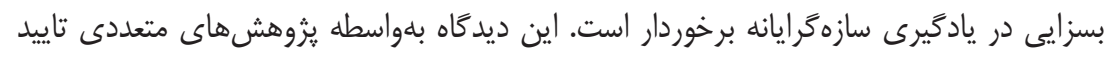

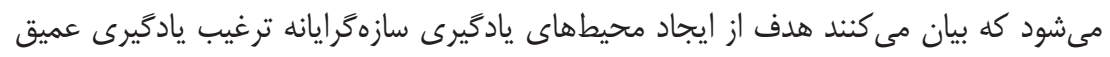
است (Dart et al., 1999; Fok \& Watkins, 2008). همجنين، مىتوان كفت ارزشهاى

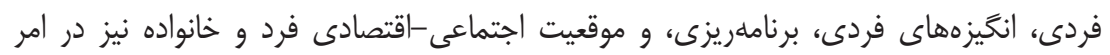
يادگيرى موثر است.

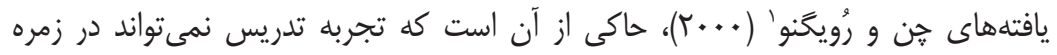

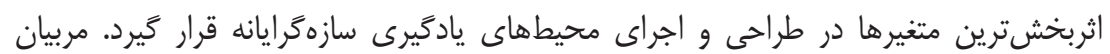
باتجربه به احتمال زياد از مهارتهاى لازم در اين زمينهها برخوردارند: تسهيل فرايند خودركردانى

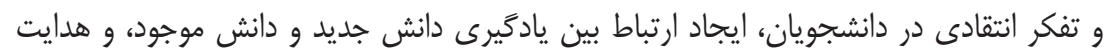

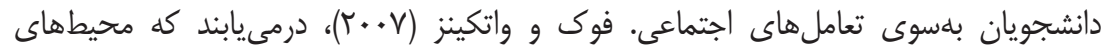

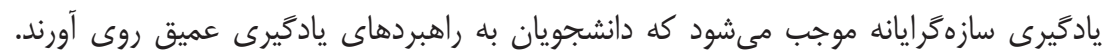

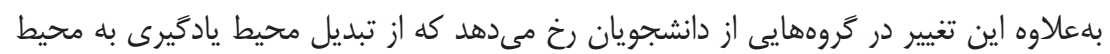
سازمخرايانه بهطور كامل اطلاع دارند.

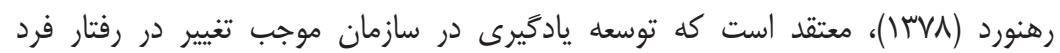

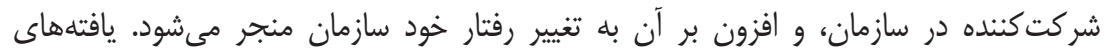

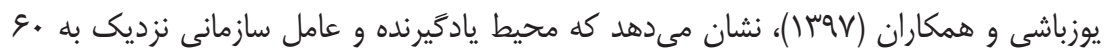

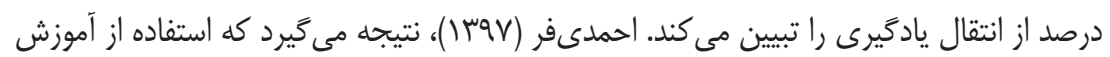

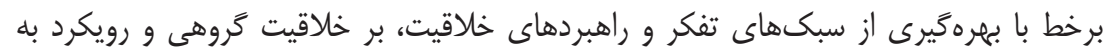

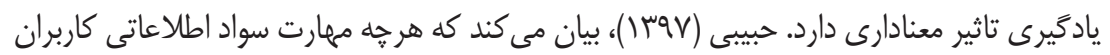

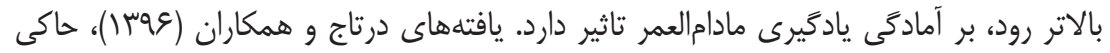

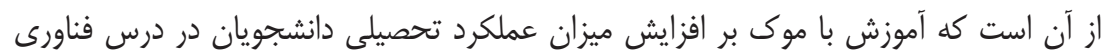
أموزشى تاثير مثبت دارد. شفيعى (عوبا)، اشاره مى كند كه اثر مستقيم ادراك از محيط يادَّيرى

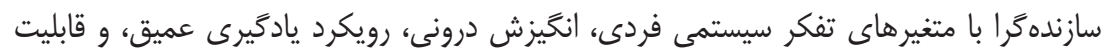

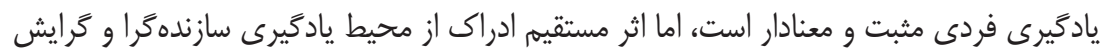

1. Chen \& Rovegno 
به يادگيرى مادامالعمر منفى و بـمعنا. همجنين، اثر مستقيه متغيرهاى تفكر سيستمى فردى، انخَيزش درونى، و قابليت يادگيرى فردى با گرايش به يادگيرى مادامالعمر مثبت و معنادار است، ولى اثر مستقيم رويكرد يادگيرى عميق به كرايش به يادگيرى مادامالعمر مثبت و بى معناست. آنجه از مرور ادبيات يثوهش برمىآيد نشان مىدهد كه متغير سازهرايى از جهار عامل

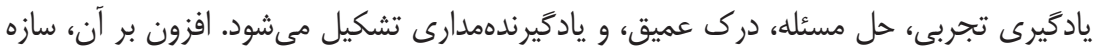
موك در بردارنده عوامل خودگردانى، استقالال، تعامل، و خوديادگيرى است. در نهايت، عامل يادكَيرى مستمر نيز شامل ينج عامل انخيزههاى فردى، موقعيت اجتماعى -اقتصادى، برنامهريزى، ارزشهاى فردى، و يادكيرى عميق است. با توجه به ييشينه يثوهش، رابطه بين متغيرها در شكل (1) (1) (نشان داده مىشود.

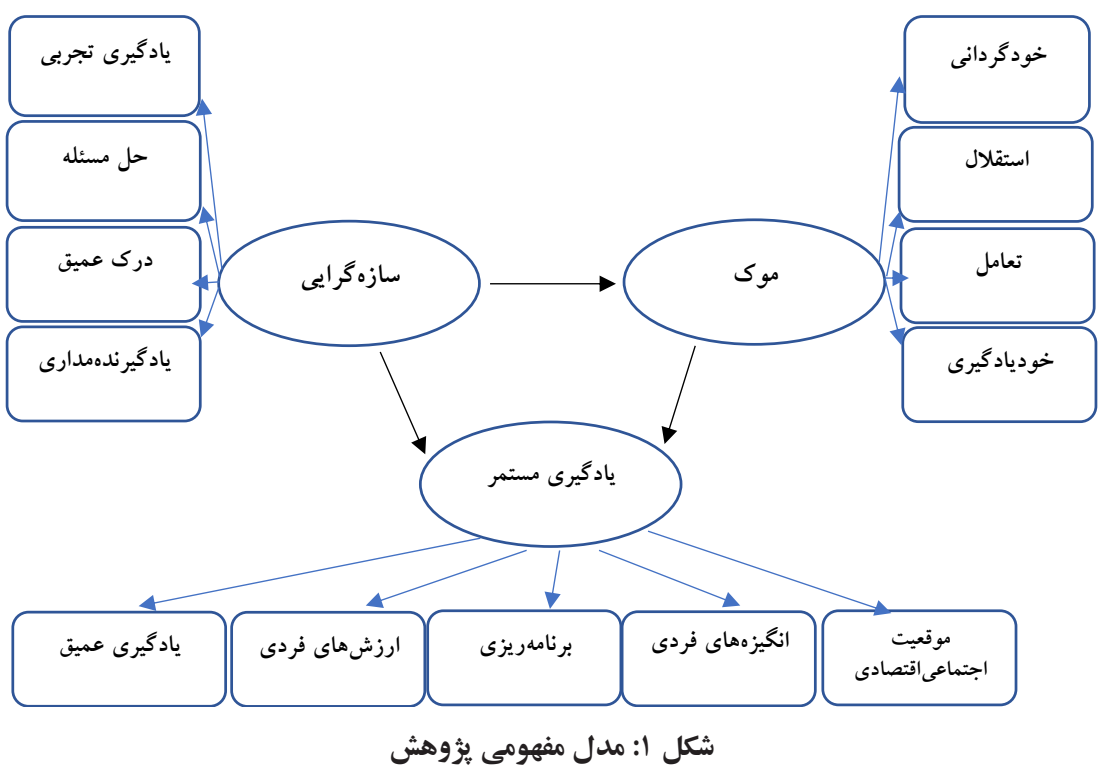

روششناسى ثخوهش

يُوهش حاضر، از نوع توصيفى است. در يزوهش توصيفى، متغيرى كنترل نمىشود، و يخوهش به بيان آنجه هست، مىيردازد. همجنين، يثوهش حاضر از نوع جندمتغيرى و همبستخى است. به ميه 


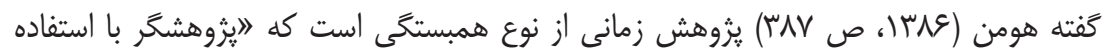

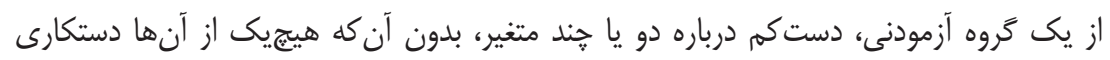

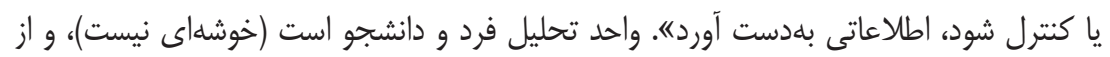
ميان دانشجويان دانشكاههاى دولتى بلَّونه تصادفى انتخاب مى شوند. با مراجعه حضورى و ايميل،

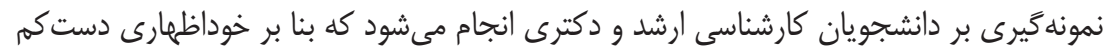
يكبار تجربه حضور در محيطهاى يادَّيرى الكترونيك ماعم از اخذ واحدهاى درسى برخط يا

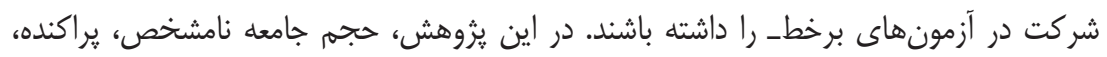

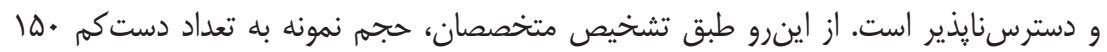

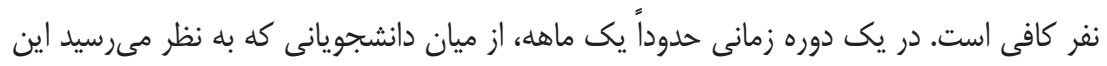

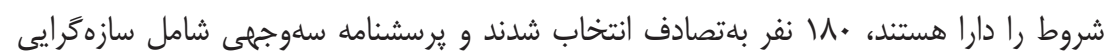

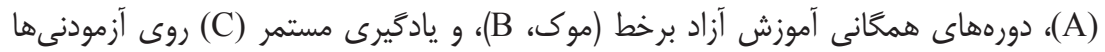

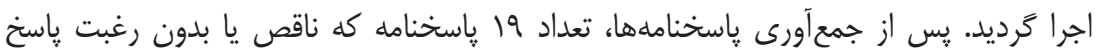

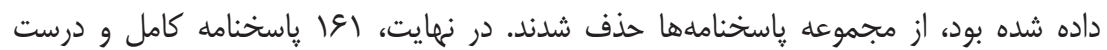

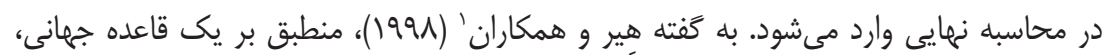

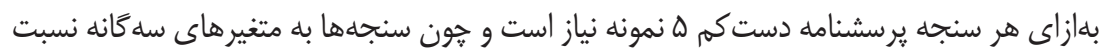

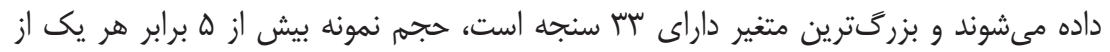
متغيرهاست، و برابر اعا نفر انتخاب مىشود. در بزوهش حاضر، از سه برسشنامه براى اندازمَّيرى سه متغير سازمَّرايى، دورههاى همكانى

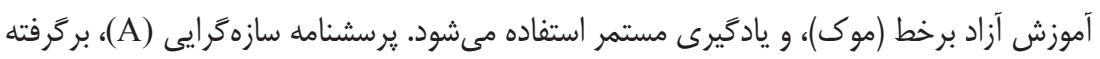

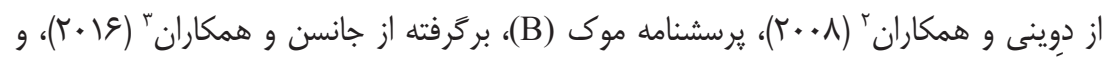

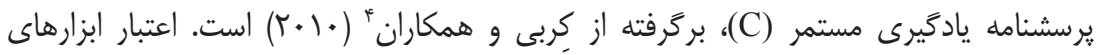

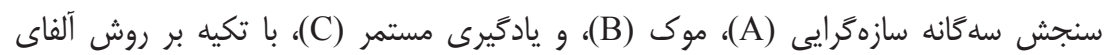

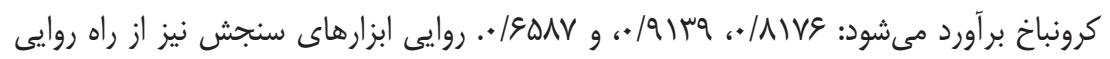

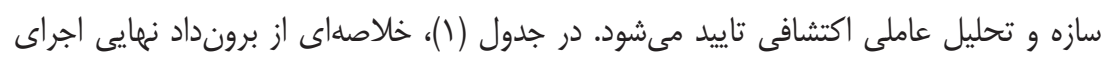
تحليل عاملى اكتشافى ارائه مىشود.

1. Hair et al.

2. DeVaney et al.

3. Jansen et al.

4. Kirby et al.

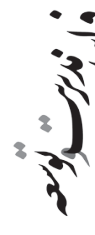


جدول 1: خلاصه برونداد نهايى اجراى تحليل عاملى اكتشافى يرسشنامههاى (A)، (B) و (C)

\begin{tabular}{|c|c|c|c|c|c|}
\hline وراريانس تبيينشده تجمى & واريانس تبيينشده & ارزش ويثُه & عامل & نماد & متغير \\
\hline$r \mu / q$ & $r M / q$ & YANAYT & 1 & \multirow{5}{*}{$\mathrm{A}$} & \multirow{5}{*}{ سازه گرايى } \\
\hline$\mu Y / \Lambda$ & $1 \cdot / 9$ & T/IVTYT & r & & \\
\hline$k y / 9$ & $9 / 1$ & $1 / 99994$ & r & & \\
\hline$\Delta T / \mathcal{T}$ & $\mathrm{V} / \mathrm{A}$ & 1/00904 & $\varphi$ & & \\
\hline$\Delta Q / T$ & $9 / \mathrm{V}$ & I/TKGIV & 0 & & \\
\hline$T \wedge / Q$ & $r \wedge / \Delta$ & $q / 4 \cdot T 19$ & 1 & \multirow{5}{*}{ B } & \multirow{5}{*}{ موى } \\
\hline$r q / 4$ & $V / 9$ & r/Q9Tq. & r & & \\
\hline $41 / 9$ & $0 / \Delta$ & I/AIVTA & $r$ & & \\
\hline$k V / l$ & $\Delta / \Gamma$ & $I / V k^{c} \cdot V^{k}$ & r & & \\
\hline $01 / 9$ & $4 / 0$ & $1 / 4 V 199$ & 0 & & \\
\hline$r \cdot / \Delta V r$ & $r \cdot / O V T$ & $r / M$. & 1 & \multirow{3}{*}{$\mathrm{C}$} & \multirow{3}{*}{ بادكيرى مستمر } \\
\hline$r_{\Lambda} / \cdot \Delta \Lambda$ & $I V / 4 \wedge \Delta$ & T/KYA & r & & \\
\hline$F V / \Lambda F I$ & q/VAr & $1 / \mu V \cdot$ & r & & \\
\hline
\end{tabular}

در يرسشنامه سازمكرايى (A)، عوامل مذاكرات دانشجويى'، هميارى'، مرتبط بودن"، اظهارنظر

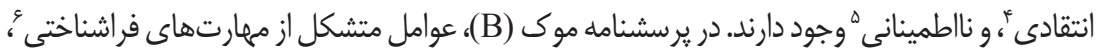

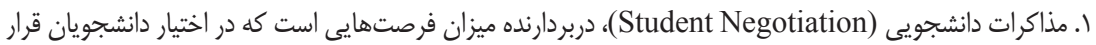

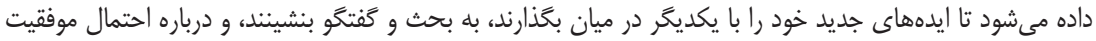

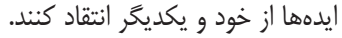

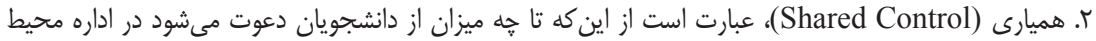

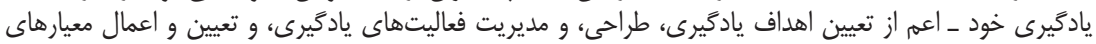

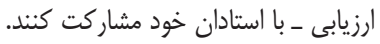

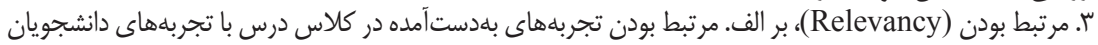

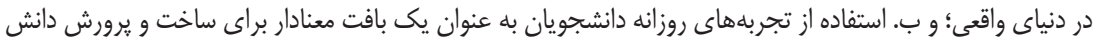
علمى دانشجويان متمركز است.

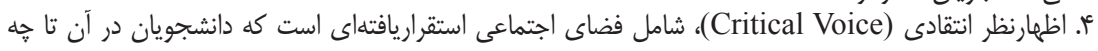

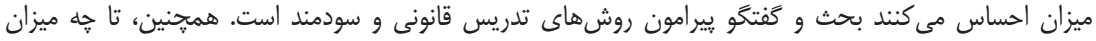

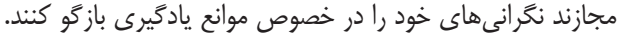

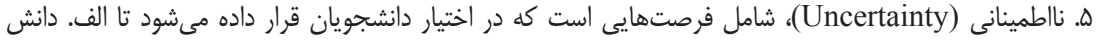

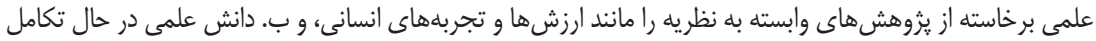

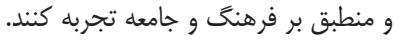
و مهارتهاى فراشناختى (Metacognitive Skills)،

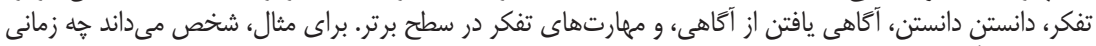

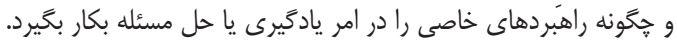




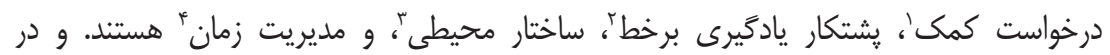

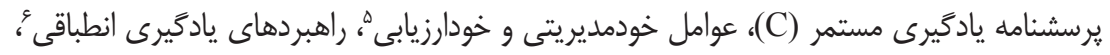
و بكارگيرى دانش و مهارتهال به عنوان مولفه معرفى مىشوند. همان گَونه كه در جدول (1) مشاهده

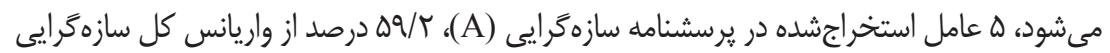
را تبيين مى كند. ه عامل استخراجشده در يرسشنامه موى (B)، و/ اه درصد از واريانس كل موك

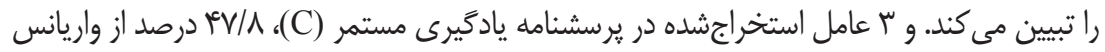
كل يادگيرى مستمر را تبيين مى كند.

يافته هاى يخووهش

براى ياسخ به يرسشهاى يك تا شش يثوهش از نرمافزار SPSS نسخه عاب، و براى اجراى

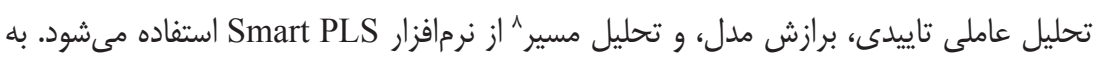
اين ترتيب، براى تجزيهوتحليل دادهها در يرسشهاى ا، r، و س كه بهطور خلاصه عبارتاند از

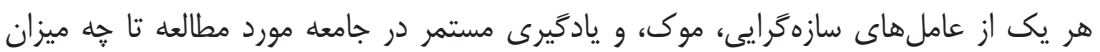
است؟ يزوهش در زمره مطالعههاى تكمتغيره قرار مى گيرد، از اينرو، مدل t تكـنمونهاى بكار برده مىشود. نتايج محاسبهها در جدول (T) مشهود است. ناگفته نماند كه در اجراى مدل فرضيههاى

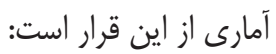

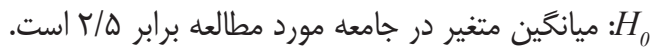
HA

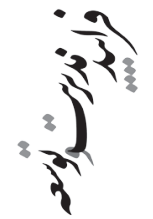

\section{Help Seeking}

ז. يُشتكار يادكَيرى برخط (Online Learning Persistence)، بر اساس تعريف مولر عبارت است از خواست

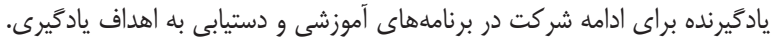

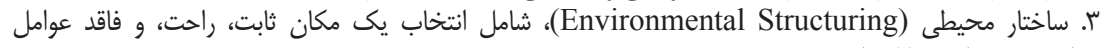

\section{Time Management}

حواسيرتى براى مطالعه است. هـ خودمديريتى و خودارزيابى (Self-Direction and Self-Evaluation)، به منزله توانايى يادگيرنده براى مديريت و

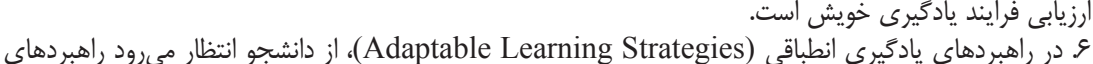

7. Application of Knowledge and Skills يادَيرى خود را با شرايط كُوناگون ساز كار كند.

8. Path Analysis 
جدول r: نتايج اجراى مدل t تكنمونهاى براى تعيين ميزان سطوح سازهر ايى، موكى، و يادكيرى مستمر در جامعه

\begin{tabular}{|c|c|c|c|c|c|c|}
\hline ميزان سطح متغيرها & فرضيه صفر & مقدار T T T T & استحراف اندارد & ميانخين & نماد & متغير \\
\hline بسيار بالا & رد مىشود & $\mid r / T V$ & .1949 & T/TTV & A 11 & مذاكرات دانشجويى \\
\hline بسيار بالا & رد مىشود & $11 / D F$ &.$|9|$. & $r / \cdot \Delta \Delta$ & $A \| r$ & هميارى \\
\hline بسيار بالا & رد مىشود & 10/A9 & $\cdot / D \wedge r$ & r/Trq & A $1 \pi$ & مرتبط بودن \\
\hline بسيار بالا & رد مىشود & $Y y / \cdot 1$ & - Mkt & $r / \mu r q$ & $A \mid f$ & اظهارنظر انتقادى \\
\hline بسيار بالا & رد مىشود & $14 / 94$ & $\cdot / \Delta \mu^{\prime} \wedge$ & r/Mre & $A 10$ & ناطمينانى \\
\hline بسيار بالا & رد مي شود & $T Y / T H$ & - ( ) & $r / 19 r$ & A tot & سازه گرايى \\
\hline بسيار بالا & رد مىشود & $1 V / 99$ & $\cdot / 4 \wedge 1$ & $r / \Lambda \Lambda r$ & B 11 & مهارتهاى فراشناختى \\
\hline بسيار بالا & رد مىشود & $1 T / 99$ & $\cdot / \Delta Q V$ & $r / \cdot \Delta V$ & $\mathrm{~B}$ IT & درخواست كمك \\
\hline بسيار بالا & شود & $1 \pi / 4$. & .109. & $r / .91$ & B & بشتكار يادگيرى \\
\hline بسيار بالا & رد مي شود & $r \mid / 49$ & •/OTV & r/rar & $B \backslash 4$ & ساختار محيطى \\
\hline بالا & رد مىشود & $N / V T$ & $\cdot / 014$ & Y/AQY & $B 10$ & مديريت زمان \\
\hline بسيار بالا & رد مىشود & $r \cdot / \bullet \wedge$ & $\cdot / 4 \cdots$ & r r/וr & tot B & موى \\
\hline بسيار بالا & رد مىشود & $10 / \pi$. &.$/ 499$ & $r / .91$ & $\mathrm{C} 11$ & خو خودارزيابى \\
\hline بسيار هايين & رد مىشود & $-9 / 9 \mathrm{~V}$ & . $/ 0$ r. & T/TYG & $C I r$ & راهبر دهاى يادگيرى \\
\hline بسيار بالا & رد مىشود & TYMG & - /OYY & T/ETY & C Ir & بكارگيرى دانش و \\
\hline بسيار بالا & رد مي شود & $11 / V^{4}$ & $\cdot M \Delta F$ & r/AYA & tot $\mathrm{C}$ & يادكيرى مستمر \\
\hline
\end{tabular}

جنانكه ستون سمت جٍ جدول (Y) نشان مىدهد، همه متغيرها بيش از حد متوسط و بالاست، بهجز متغير راهبردهاى يادگيرى انطباقى كه كمتر از حد متوسط و بسيار يايين است. براى پاسخ به يرسشهاى أ، ه، و ع كه عبارتاند از رتبلبندى هر يك از عاملهاى سازمگرايى، موك، و يادگيرى مستمر در جامعه مورد مطالعه كدام است؟ يزوهش در زمره مطالعههاى توصيفى قرار مى مدل فريدمن بكار برده مىشود. نتايج بهدستآمده از اجراى مدل مذكور در جدول (؟ّ) مشهود است. 
جدول بّ: رتبهبندى عاملهاى سازهز ايى، موك، و ياد كيرى مستمر در جامعه مورد مطالعه

\begin{tabular}{|c|c|c|c|c|c|c|c|}
\hline رتبه & ميانگين & نماد & متغير & رتبه & ميانخين رتبه & نماد & متغير \\
\hline 1 & $r / \mu q$ & AlY & اظهارنظر انتقادى & r & $\Gamma / \tau$. & $A 11$ & مذاكرات دانشجويى \\
\hline q & $r / V Q$ & $A 10$ & ناطمينانى & $\Delta$ & $r / \Delta Q$ & $A \mid r$ & هميارى \\
\hline- & - & - & - & r & $r / l \cdot$ & Alr & مرتبط بودن \\
\hline
\end{tabular}

\begin{tabular}{|c|c|c|c|c|c|c|c|}
\hline & $\begin{array}{c}\text { Cases } \\
191\end{array}$ & & $\begin{array}{l}\text { Chi-Square } \\
\text { rq/४ধ4૬ }\end{array}$ & \multicolumn{2}{|c|}{ D.F.Y } & \multicolumn{2}{|r|}{$\begin{array}{c}\text { Significance } \\
\cdot / \ldots\end{array}$} \\
\hline رتبه & ميانخينرتبه & نماد & متغير & رتبه & ميانگين رتبه & 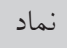 & متغير \\
\hline 1 & $r / 9 \mu$ & $\mathrm{B} \mid \mathrm{t}$ & ساختار محيطى & r & $r / r \mid$ & B)1 & مهارت هاى فراشناختى \\
\hline$\Delta$ & $r / \Lambda$ & $B \backslash Q$ & مديريت زمان & i & r/VI & $\mathrm{B}) \mathrm{r}$ & درخواست كمك \\
\hline- & - & - & - & r & $r / 9 V$ & BIr & يشتكار ياد گيرى برخط \\
\hline & $\begin{array}{c}\text { Cases } \\
|9|\end{array}$ & & $\begin{array}{l}\text { Chi-Square } \\
\text { I. V/TY } \Delta \Delta\end{array}$ & \multicolumn{2}{|c|}{ \&.D.F } & \multicolumn{2}{|r|}{$\begin{array}{c}\text { Significance } \\
\cdot / \ldots\end{array}$} \\
\hline رتبه & ميانكينرتبه & نماد & متغير & رتبه & ميانخين رتبه & نماد & متغير \\
\hline 1 & $r / V$. & Cir & بكار كيرى دانش & r & T/19 & $\mathrm{C} 11$ & خودمديريتى و خودارزيابى \\
\hline- & - & - & - & r & $1 / 1 K^{\mathrm{c}}$ & $\operatorname{CIT}$ & راهبردهاى يادگيرى انطباقى \\
\hline & $\begin{array}{c}\text { Cases } \\
|9|\end{array}$ & & $\begin{array}{l}\text { Chi-Square } \\
\text { ץ. / rqvQ }\end{array}$ & \multicolumn{2}{|r|}{ D.F.Y } & \multicolumn{2}{|r|}{$\begin{array}{c}\text { Significance } \\
\cdot / \ldots\end{array}$} \\
\hline
\end{tabular}

همان طور كه در جدول (بّ) مشهود است، رتبه عاملهاى متغيرها بدين شرح است: در جامعه

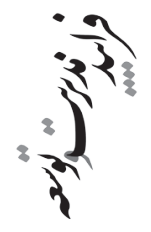
مورد مطالعه و در رابطه با متغير سازهرايى، اظهارنظر انتقادى در رتبه نخست، مذاكرات دانشجويى در رتبه دوم، مرتبط بودن در رتبه سوم، ناطمينانى در رتبه جهارم، و هميارى در رتبه ينجم قرار مى گيرد. همجنين، در متغير موك، ساختار محيطى در رتبه نخست، مهارتهاى فراشناختى در رتبه دوم، يشتكار يادگيرى برخط در رتبه سوم، درخواست كمك در رتبه جهارم، و مديريت زمان

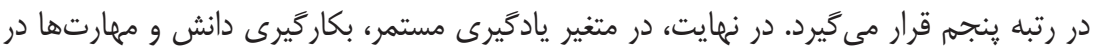

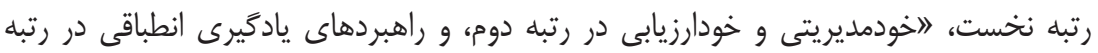




\section{نتايج اجراى مدل تحليل مسير}

קنانكه اشاره شد، براى اجراى تحليل عاملى تاييدى، برازش مدل، و تحليل مسير از

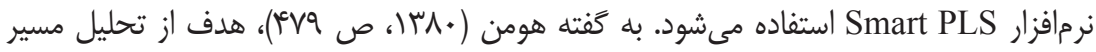

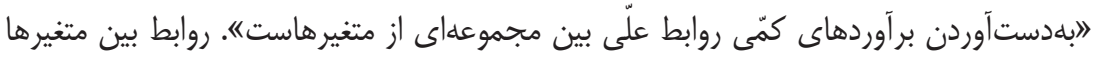
در يك جهت جريان مىيابد و به عنوان مسيرهاى متمايزى در نظر كرفته مىشود. مفاهيم تحليل

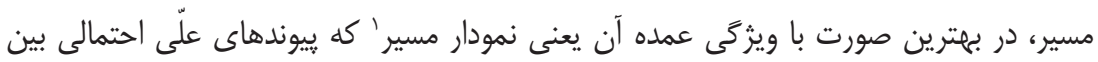

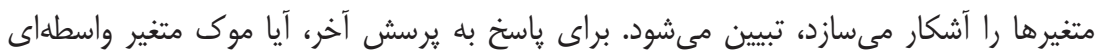

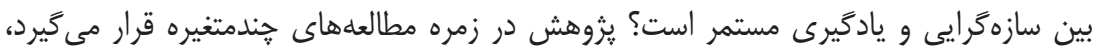

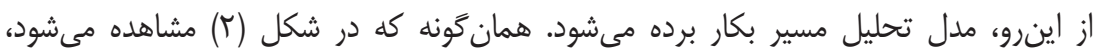

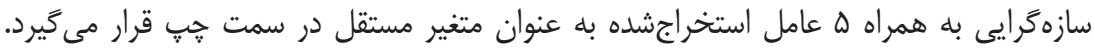

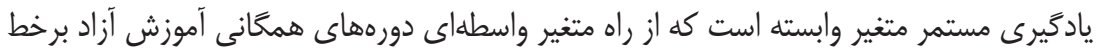

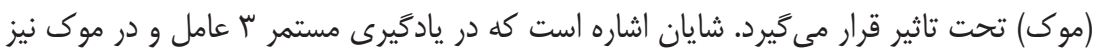

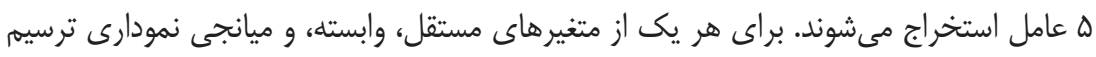

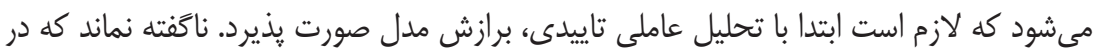
تحليل مسير به هر سه يرسش به صورت يكجا ياسخ داده مىشود.

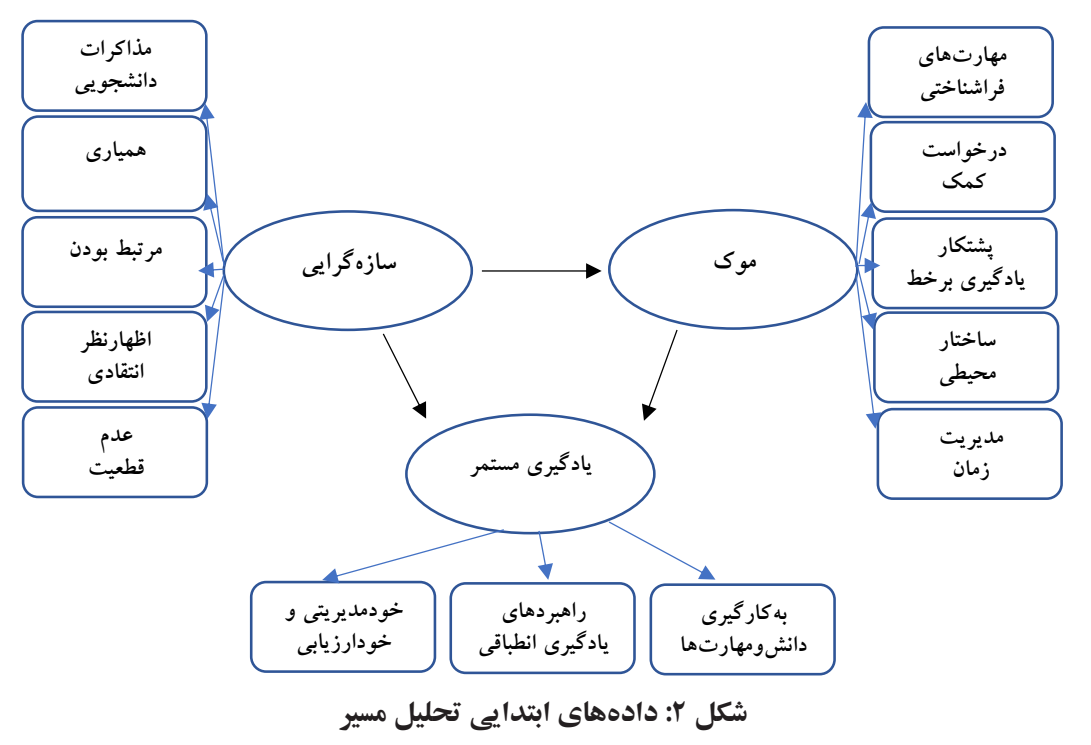

1. Path Diagram 
در تحليل عاملى تاييدى لازم است به كمك ضرايب مربوطه برازش مدل تاييد شود. اين امر

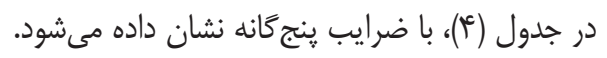

جدول f: مشخصه هاى برازند

\begin{tabular}{|c|c|c|c|}
\hline شاخص نيكويى برازش & محدوده قابل قبول & مقدار مشاهدهده & مناسب/ نامناسب \\
\hline 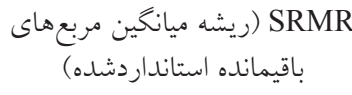 & 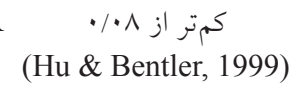 & $\cdot 11 \cdot 4$ & برازش نامناسب \\
\hline d_ULS & $\begin{array}{c}\text { كمتر از } 190 \text { (Henseler et al., 2015) }\end{array}$ & $\cdot / V T$. & برازش مناسب \\
\hline d_G & $\begin{array}{c}\text { كمتر از } 19 \Delta \\
\text { (Henseler et al., 2015) }\end{array}$ & $\cdot / T V q$ & برازش مناسب \\
\hline $\begin{array}{c}\text { Chi-Square } \\
\text { (سطح تحت يوشش كاىدو) }\end{array}$ & بيشتر از ه•٪ & $\mid K Y / \varphi \Delta Q$ & برازش مناسب \\
\hline 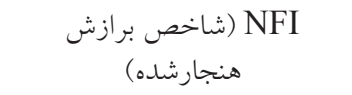 & 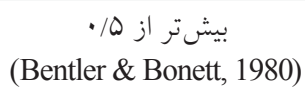 &.$/ 9 \mathrm{TV}$ & مناسب \\
\hline
\end{tabular}

جنانكه در جدول (أ) مشاهده مىشود، در شاخص SRMR به مقدار \& + / + و سطح بحرانى

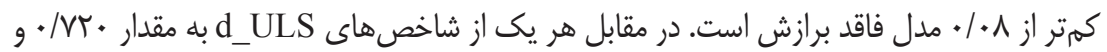

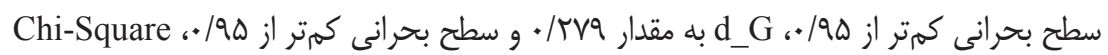

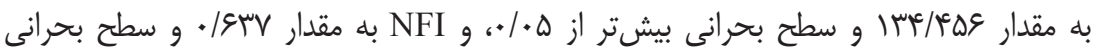
بيشتر از ه/ • بلهخبى برازش مدل را تاييد مى كنند. در مرحله بعد، عاملهاى موثر در تحليل

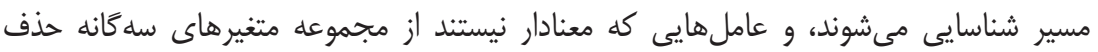
مىشوند. نتايج حاصل از اجراى اين مرحله در شكل (ب) مشهود است. در نتيجه، از سازمكرايى

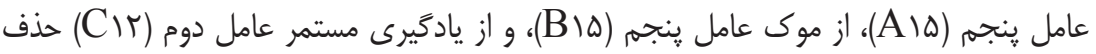
مىشود. همجنين، ضرايب معنادارى عاملهاى باقيمانده تعيين مىشود. از سوى ديخر، همبستخى ئى

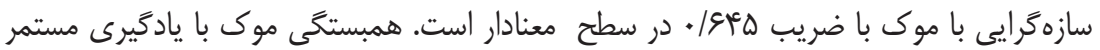

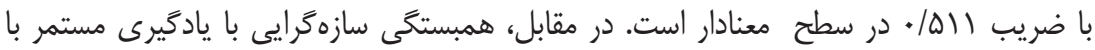

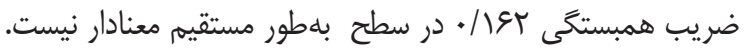

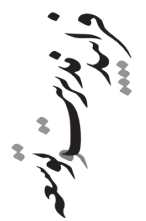

2
2
0
2
2
1
3
3
5
5
1
3
3
0
2
1
3
7
5
0 

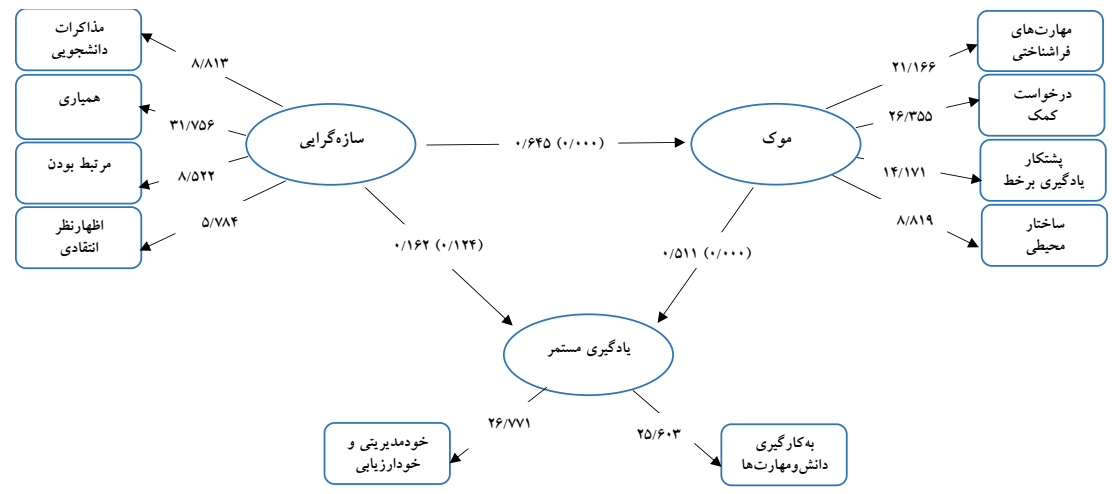

شكل ": مدل پس از اجراى تحليل عاملى تاييدى و برازش مدل

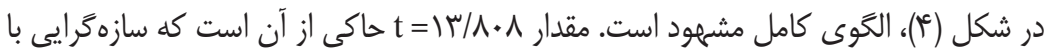

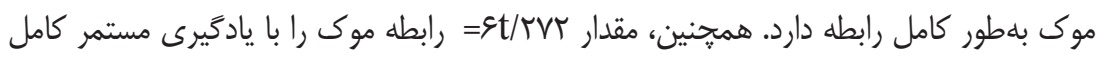

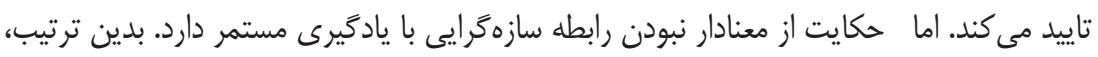

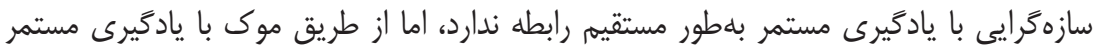

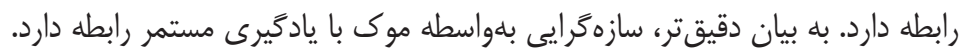

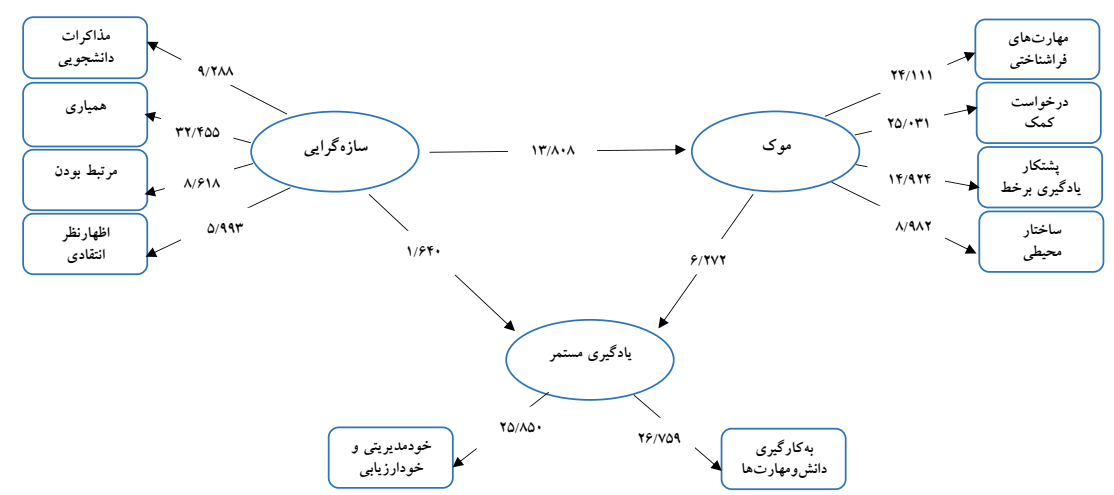

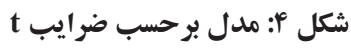


لازم به اشاره است كه در شكل (ه)، تحليل عاملى تاييدى نشان مىدهد موك //أث درصد

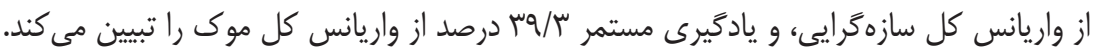

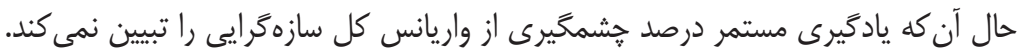

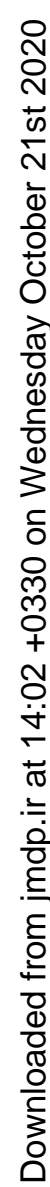

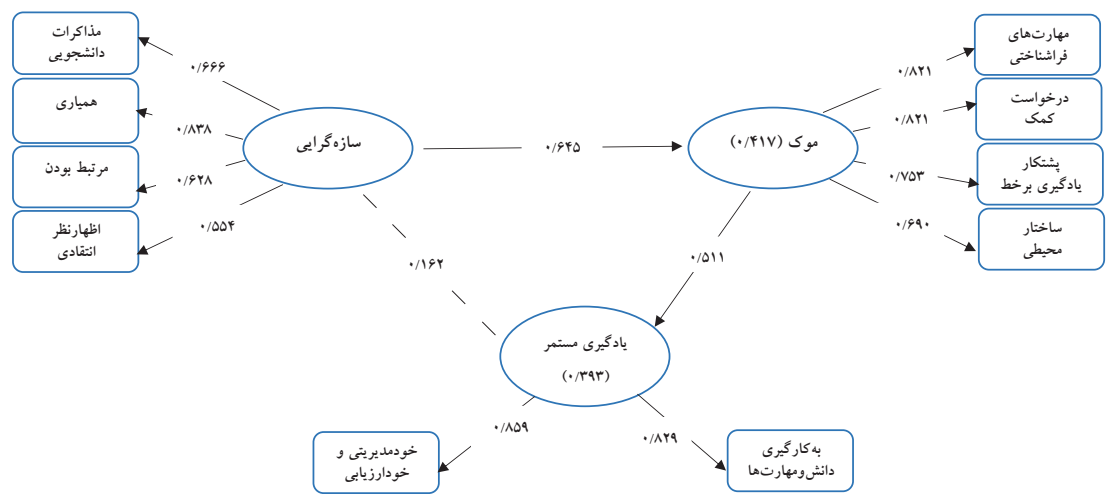

شكل ه: مدل نهايى و تعيين درصد واريانس تبيينشده توسط متغيرهاى موكى و يادكيرى مستمر

بحث و نتيجه Fيرى

همانطور كه ييشتر كَته شد، يُوهش حاضر با هدف افزايش يادكيرى مستمر بر پايه

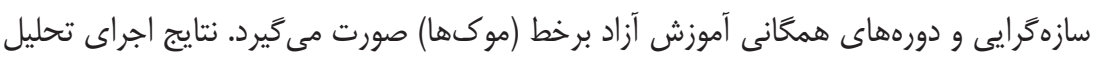

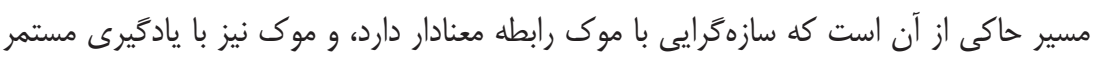

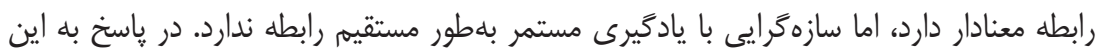
يرسش كه آيا موك متغير واسطهاى بين سازهگرايى و يادگيرى مستمر است؟ نتايج نشان مىدهد كه سازمگرايى با يادگيرى مستمر رابطه مستقيم ندارد. در يثوهش شفيعى (عوسا)، اثر مستقيه

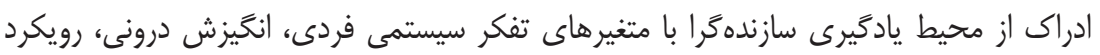
يادگيرى عميق، و قابليت يادگيرى فردى مثبت و معنادار است، اما اثر مستقيم ادراك از محيط

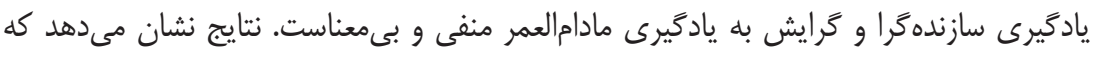

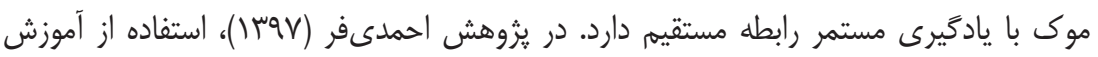
برخط با بهرهگيرى از سبكهاى تفكر و راهبردهاى خلاقيت بر خلاقيت گروهى و رويكرد به 
يادگيرى تاثير معنادارى دارد. حبيبى (YVII)، بيان مى كند كه هرجه مهارت سواد اطلاعاتى كاربران

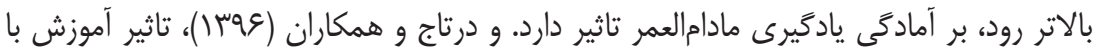

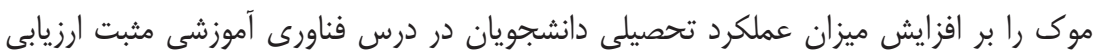
مى كنند. نياز به يادآورى است كه در اجراى تحليل عاملى تاييدى حدود الث درصد از واريانس كل در

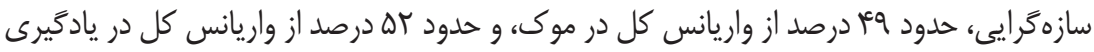

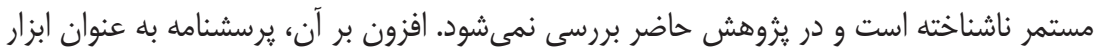

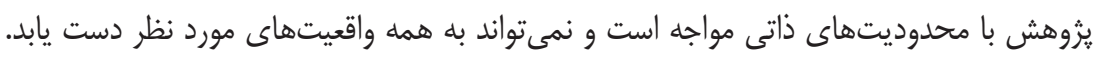

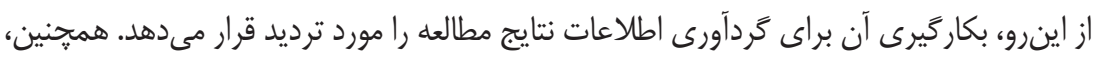

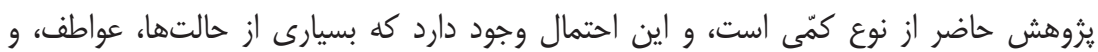
روحيههاى افراد رادر نظر نخيرد.

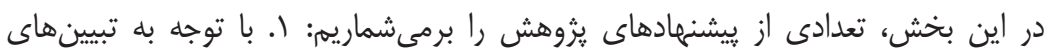

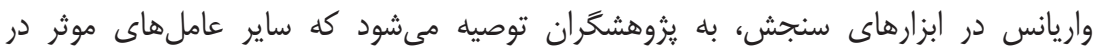

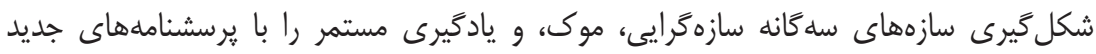
شناسايى كنند؛ ז. در متغير يادگيرى مستمر، سطح عامل راهبردهاى يادَّيرى انطباقى در جامعه

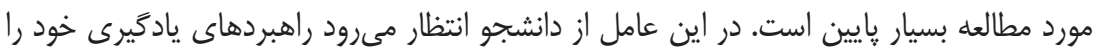

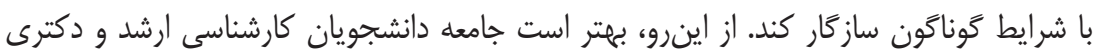

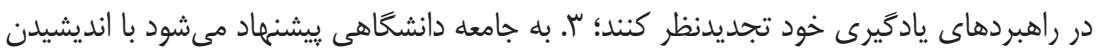

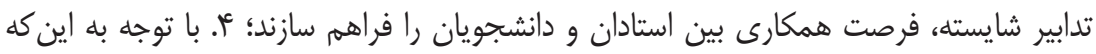
موك با يادكيرى مستمر رابطه مستقيم دارد، به يزوهشكران بيشنهاد مى شود ساير متغيرهاى

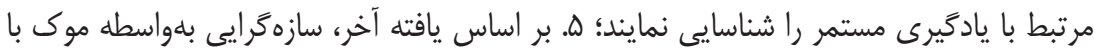

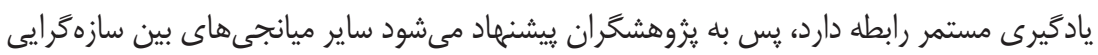

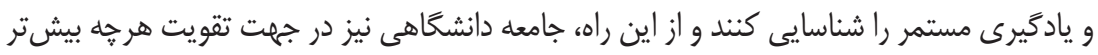




\section{منابع}

$$
\text { الف) فارسى }
$$

احمدى فر، مهرداد (Vوسا). طراحى آموزش مبتنى بر يادكيرى مشاركتى برخط و تاثير آن بر خلاقيت كروهى

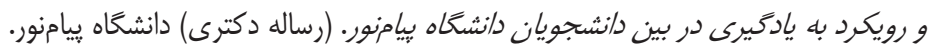

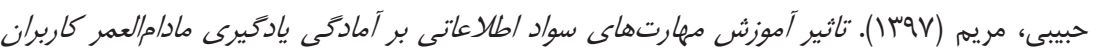
كتابخانههاى عمومى. (يايان نامه كارشناسى ارشد) دانشعاه بيرجند.

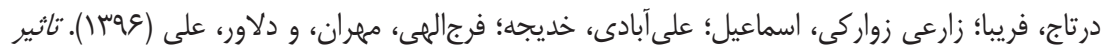

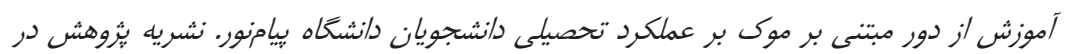

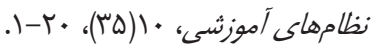

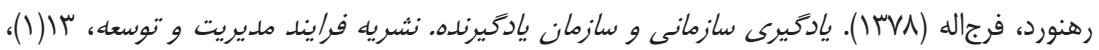
كنr

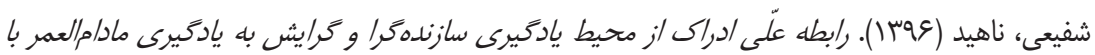

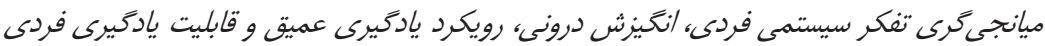

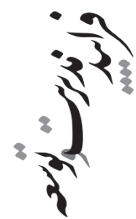

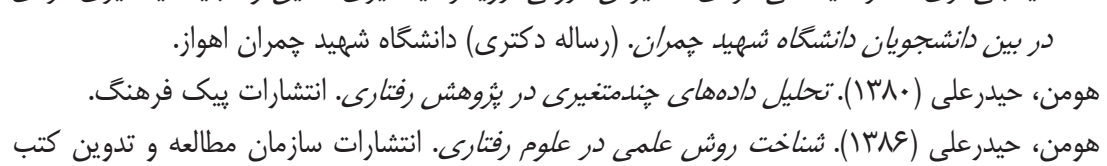

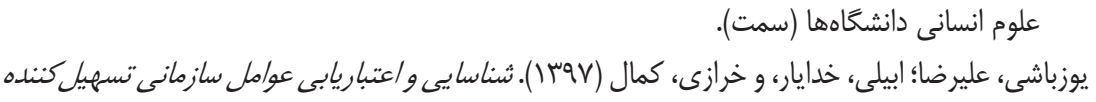

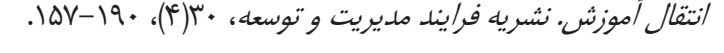

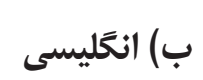

2
2
0
2
2
1
3
$\vdots 3$
$\cdot 5$
5
1
3
3
0
2
1
3
7
0
$=$

Abdal-Haqq, I. (1998). Constructivism in Teacher Education: Considerations for Those Who Would Link Practice to Theory. ERIC Digest.

Aldamigh, N., \& Namukasa, I. (2018). Ontario Teachers' Understanding and Practices of Reform Instruction: A Case Study of Constructivism. The University of Western Ontario.

Altun, S., \& Büyükduman, F. I. (2007). Teacher and Student Beliefs on Constructivist Instructional Design: A Case Study. Kuram ve Uygulamada Egitim Bilimleri, 7(1), 30-39.

Bentler, P. M., \& Bonett, D. G. (1980). Significance Tests and Goodness of Fit in the Analysis of Covariance Structures. Psychological Bulletin, 88(3), 588-606. 
Bolton-Gary, C. (2013). Living Theory: Dramatization in Educational Psychology. International Journal of University Teaching and Faculty Development, 4(3), 147.

Brooks, M. (1987). Curriculum Development from a Constructivist Perspective. Educational Leadership, 44(4), 63-67.

Bruff, D. O., Fisher, D. H., McEwen, K. E., \& Smith, B. E. (2013). Wrapping a MOOC: Student Perceptions of an Experiment in Blended Learning. Journal of Online Learning and Teaching, 9(2), 187-199.

Caine, R. N., \& Caine, G. (1991). Making Connections: Teaching and the Human Brain. Association for Supervision and Curriculum Development.

Catalano, A. J. (2018). Measurements in Distance Education: A Compendium of Instruments, Scales, and Measures for Evaluating Online Learning: Routledge.

Caulfield, M., Collier, A., \& Halawa, S. (2013). Rethinking Online Community in MOOCs Used for Blended Learning. EDUCAUSE Review Online, 1-11.

Chen, R. T.-H., \& Bennett, S. (2012). When Chinese Learners Meet Constructivist Pedagogy Online. Higher Education, 64(5), 677-691.

Chen, W., \& Rovegno, I. (2000). Examination of Expert and Novice Teachers' Constructivist-Oriented Teaching Practices Using a Movement Approach to Elementary Physical Education. Research Quarterly for Exercise and Sport, 71(4), 357-372.

Dart, B., Burnett, P., Boulton-Lewis, G., Campbell, J., Smith, D., \& McCrindle, A. (1999). Classroom Learning Environments and Students' Approaches to Learning. Learning Environments Research, 2(2), 137-156.

DeVaney, T. A., Adams, N. B., \& Elliott, C. B. (2008). Assessment of Online Learning Environments: Using the OCLES (20) with Graduate Level Online Classes. Journal of Interactive Online Learning, 7(3), 165-174.

Dillon, C., \& Greene, B. A. (2003). Learner Differences in Distance Learning: Finding Differences that Matter. Handbook of Distance Education (235244): Lawrence Erlbaum Associates.

Downes, S. (2007). What Connectivism Is. Retrieved from http://halfanhour. blogspot.com/2007/02/what-connectivism-is.html

Downes, S. (2008). Connectivism: A Theory of Personal Learning. http:// www.slideshare. Net/Downes/connectivism-a-theory-of-personal-learning.

Downes, S. (2009). Connectivism Dynamics in Communities. Half an Hour. Elérhetö: http://halfanhour.blogspot.com/2009/02/connectivist-dynamics-in communities.

Downes, S. (2013). The Quality of Massive Open Online Courses. International Handbook of E-Learning, 1(1), 65-77.

Entwistle, N. (2005). Contrasting Perspectives on Learning. The Experience 
of Learning: Implications for Teaching and Studying in Higher Education (106-125). Edinburgh: University of Edinburgh.

Ertmer, P. A., \& Newby, T. J. (2013). Behaviorism, Cognitivism, Constructivism: Comparing Critical Features from an Instructional Design Perspective. Performance Improvement Quarterly, 26(2), 43-71.

Firmin, R., Schiorring, E., Whitmer, J., Willett, T., Collins, E. D., \& Sujitparapitaya, S. (2014). Case Study: Using MOOCs for Conventional College Coursework. Distance Education, 35(2), 178-201.

Fok, A., \& Watkins, D. (2008). Does a Critical Constructivist Learning Environment Encourage A Deeper Approach to Learning? The Asia-Pacific Education Researcher, 16(1), 1-10.

Garrison, R. D. (2003). Modes of Interaction in Distance Education: Recent Developments and Research Questions. Handbook of Distance Education (161-168): Lawrence Erlbaum Associates.

Gillani, N., \& Eynon, R. (2014). Communication Patterns in Massively Open Online Courses. The Internet and Higher Education, 23(1), 18-26.

Gordon, M. (2009). The Misuses and Effective Uses of Constructivist Teaching. Teachers and Teaching: Theory and Practice, 15(6), 737-746.

Hair, J. F., Black, W. C., Babin, B. J., Anderson, R. E., \& Tatham, R. L. (1998). Multivariate Data Analysis (Vol. 5): Prentice hall Upper Saddle River, NJ.

Hartley, K., \& Bendixen, L. D. (2001). Educational Research in the Internet Age: Examining the Role of Individual Characteristics. Educational Researcher, 30(9), 22-26.

Henseler, J., Ringle, C. M., \& Sarstedt, M. (2015). A New Criterion for Assessing Discriminant Validity in Variance-Based Structural Equation Modeling. Journal of the Academy of Marketing Science, 43(1), 115-135.

Hermida, J. (2014). Facilitating Deep Learning: Pathways to Success for University and College Teachers: Apple Academic Press.

Holotescu, C., Grosseck, G., CREȚU, V., \& Naaji, A. (2014). Integrating MOOCs in Blended Courses. Elearning \& Software for Education, 1(1), 243-250.

Hood, N., \& Littlejohn, A. (2016). MOOC Quality: The Need for New Measures. Journal of Learning for Development-JL4D, 3(3), 28-42.

Houghton, W. (2004). Engineering Subject Centre Guide: Learning and Teaching Theory for Engineering Academics: (C) Higher Education Academy Engineering Subject Centre, Loughborough University.

Hu, L. t., \& Bentler, P. M. (1999). Cutoff Criteria for Fit Indexes in Covariance Structure Analysis: Conventional Criteria versus New Alternatives. Structural Equation Modeling: A Multidisciplinary Journal, 6(1), 1-55. 
Hung, D. (2001). Design Principles for Web-Based Learning: Implications from Vygotskian Thought. Educational Technology, 41(3), 33-41.

Israel, M. J. (2015). Effectiveness of Integrating MOOCs in Traditional Classrooms for Undergraduate Students. International Review of Research in Open and Distributed Learning, 16(5), 102-118.

Jansen, R. S., Van Leeuwen, A., Janssen, J., Kester, L., \& Kalz, M. (2017). Validation of the Self-Regulated Online Learning Questionnaire. Journal of Computing in Higher Education, 29(1), 6-27.

Jordan, K. (2015). Massive Open Online Course Completion Rates Revisited: Assessment, Length and Attrition. International Review of Research in Open and Distributed Learning, 16(3), 341-358.

Kamii, C., \& Ewing, J. K. (1996). Basing Teaching on Piaget's Constructivism. Childhood Education, 72(5), 260-264.

Kirby, J. R., Knapper, C., Lamon, P., \& Egnatoff, W. J. (2010). Development of a Scale to Measure Lifelong Learning. International Journal of Lifelong Education, 29(3), 291-302.

Krahenbuhl, K. S. (2016). Student-Centered Education and Constructivism: Challenges, Concerns, and Clarity for Teachers. The Clearing House: A Journal of Educational Strategies, Issues and Ideas, 89(3), 97-105.

Littlejohn, A., \& Milligan, C. (2015). Designing MOOCs for Professional Learners: Tools and Patterns to Encourage Self-Regulated Learning. ELearning Papers, 42(4), 1-10.

Littlejohn, A., Hood, N., Milligan, C., \& Mustain, P. (2016). Learning in MOOCs: Motivations and Self-Regulated Learning in MOOCs. The Internet and Higher Education, 29(1), 40-48.

Margaryan, A., Bianco, M., \& Littlejohn, A. (2015). Instructional Quality of Massive Open Online Courses (MOOCs). Computers \& Education, 80(1), 77-83.

Marques, J. (2013). A Short History of MOOCs and Distance Learning. Retrieved from http://moocnewsandreviews.com/a-short-historyof-moocs-and-distance-learning/

McRae, P. (2006). Echoing Voices-Emerging Challenges for Educational Practice on the Internet. Paper Presented at the E-Learn: World Conference on E-Learning in Corporate, Government, Healthcare, and Higher Education.

Milligan, C., Littlejohn, A., \& Margaryan, A. (2013). Patterns of Engagement in Connectivist MOOCs. Journal of Online Learning and Teaching, 9(2), 149-159.

Phillips, D. C. (2000). Constructivism in Education: Opinions and Second 
Opinions on Controversial Issues. Ninety-Ninth Yearbook of the National Society for the Study of Education: ERIC.

Reich, J. (2014). MOOC Completion and Retention in the Context of Student Intent. EDUCAUSE Review Online, 8.

Richardson, V. (2003). Constructivist Pedagogy. Teachers College Record, 105(9), 1623-1640.

Siemens, G. (2005). Connectivism: A Learning Theory for the Digital Age. International Journal of Instructional Technology and Distance Learning. Obtained through the Internet: http://www. Idtl. Org/Journal/Jam_05/ article01. Htm. [Accessed Sept. 2008].

Siemens, G. (2012). MOOCs are really a Platform. ELearnSpace. Available at: http://www.elearnspace.org/blog/2012/07/25/moocs-are-really-a-platform/.

Turkmen, H., \& Pedersen, J. E. (2003). Learning Environments in Our Science Classrooms: The View of International Students. Science Education International, 14(1), 21-29.

Unal, G., \& Akpinar, E. (2006). To What Extent Science Teachers are Constructivist in Their Classrooms? Journal of Baltic Science Education, 2(10), 40-50.

Von Glasersfeld, E. (1989). Constructivism in Education. The International Encyclopedia of Education-Research and Studies, 162-163.

Von Glasersfeld, E. (1995). A Constructivist Approach to Teaching In L. Steffe \& J. Gale (Eds.), Constructivism in Education (pp. 3-16): New Jersey: Lawrence Erlbaum Associates, Inc.

Yager, R. E. (1991). The Constructivist Learning Model. The Science Teacher, 58(6), 52-57.

Zahorik, J. A. (1995). Constructivist Teaching. Fastback Seri No. 390. Phi Delta Kappa Educational Foundation: Bloomington, IN.

Zhenghao, C., Alcorn, B., Christensen, G., Eriksson, N., Koller, D., \& Emanuel, E. (2015). Who's Benefiting from MOOCs, and Why. Harvard Business Review, 25(1), 2-8. 